Article

\title{
Synthesis and in silico docking of new pyrazo- lo[4,3-e]pyrido[1,2-a]pyrimidine-based cytotoxic agents
}

\author{
Mabrouk Horchani ${ }^{1}$, Niels V. Heise ${ }^{2}$, Sophie Hoenke ${ }^{2}$, René Csuk ${ }^{2,}{ }^{*}$, Abdel Halim Harrath ${ }^{3}$, Hichem Ben Jannet ${ }^{1}$ \\ * and Anis Romdhane ${ }^{1}$ \\ 1 Laboratory of Heterocyclic Chemistry, Natural Products and Reactivity, Medicinal Chemistry and Natural \\ Products (LR11ES39), Faculty of Sciences Monastir, University of Monastir, 5000 Monastir, Tunisia; \\ horchani.mabrouk@gmail.com (M.H.); anis_romdhane@yahoo.fr (A.R.) \\ 2 Organic Chemistry, Martin-Luther-UniversityHalle-Wittenberg, Kurt-Mothes-Str. 2, D-06120 Halle (Saale), \\ Germany; sophie.hoenke@chemie.uni-halle.de (S.H.); niels.heise@student.uni-halle.de (N.H.) \\ 3 College of Science, Department of Zoology, King Saud University, Riyadh, Saudi Ara- \\ bia;halim.harrath@gmail.com (A.H.H.) \\ * Correspondence: rene.csuk@chemie.uni-halle.de (R.C.); Hichem.bjannet@gmail.com (H.B.J.);
}

\begin{abstract}
To explore a new set of anticancer agents, a novel series of pyrazolo[4,3-e]pyrido[1,2-a]pyrimidine derivatives 7a-1 have been designed and synthesized via cyclocondensation reactions of pyrazolo-enaminone 5 with a series of arylidene malononitriles; compound 5 was obtained from 5-amino-4-cyanopyrazole (3). The structures of the target compounds 7a-1 were investigated by spectral techniques and elemental analysis (IR, UV-Vis, ${ }^{1} \mathrm{H}$ NMR, ${ }^{13} \mathrm{C}$ NMR and ESI-MS). All compounds were evaluated for their in vitro cytotoxicity employing a panel of different human tumor cell lines, A375, HT29, MCF7, A2780, FaDu as well as non-malignant NIH 3 T3 and HEK293 cells. It has been found that the conjugate 7e was the most active towards many cell lines with $\mathrm{EC}_{50}$ values ranging between 9.1 and $13.5 \mu \mathrm{M}$, respectively. Moreover, in silico docking studies of $7 \mathrm{e}$ with six anticancer drug targets, i.e. DHFR, VEGFR2, HER-2/neu, hCA-IX, CDK6 and LOX also was performed, in order to gain some insights into their putative mode of binding interaction and to estimate the free binding energy of this bioactive molecule.
\end{abstract}

Keywords: pyrazolo-pyrido-pyrimidines; cytotoxicity; tumor cell lines; SAR; in silico docking.

\section{Introduction}

At present, cancer still constitutes a tremendous frightful disease for numerous patients worldwide. This disease is regarded as one of the foremost causes of mortality, thus endangering health and life of humans. Thereby, cancer cases surpassed 14 million persons in 2012, and it is expected to affect 22 million persons in 2030[1]. Regardless of their state of development and economic prosperity in all countries worldwide, the number of persons suffering from malignant melanoma, colon, breast, human ovarian carcinoma or pharynx carcinoma increased during the last decade. Thereby, besides surgery and radiotherapy, chemotherapy is the most currently used treatment to cure the various types of cancers[2]. Nowadays, chemotherapy applying a set of drugs acting by different mechanisms is one of the most promising techniques being applied to treat cancer.

Thus, in spite of all progress to treat and cure cancer patients there is still need to search for and to develop novel anticancer agents holding superior efficacy but giving rise to minimal side effect. Therefore, the identification of new chemical entities being more reliable and efficient remains a major challenge for medicinal chemists. As a consequence, the synthesis of small molecules still represents a potent and effective strategy to supply novel chemical entities for cancer therapy. 
In this context, heterocyclic compounds, especially those holding more than one non-carbon ring atom have played a key role in the field of medicinal chemistry $[3,4]$. Furthermore, the previously reported results from literature reveal that the combination of two or more bioactive heterocyclic pharmacophores into the same molecule appears to be an effective tool for designing new chemical entities of improved activity. Thereby, pyrazole-fused pyrimidines constitute a promising versatile class of heterocyclic scaffolds having always attracted much interest from chemists owing to their outstanding potential, such as antitumor [5], anti-inflammatory [6], anticancer and anti-5-lipoxygenase [7], antibacterial [8], antitubercular [9], and especially cytotoxic activities (Fig. 1 (A, B, C and D)) [10-13].

Pyrido-pyrimidines have, for a long time, attracted the interests of both biological and synthetic researchers alike due to their various biological therapeutic properties such as anticonvulsant [14], antitumor [15], anti-proliferative [16], antifungal [17], adenosine kinase inhibitors [18] in addition to cytotoxic activities (Fig. 1 (E, F and G)) [19, 20].

A review of the literature has shown in several cases that amino and cyano functions can be involved in some interesting interactions towards target enzymes. Indeed, various constructed heterocyclic compounds gained much attention owing to their cytotoxic and anticancer activities especially in cases where the $\mathrm{NH}_{2}$ group shows conjugation when it is tethered with a pyrimidine (Fig. 2 (A and B)) [21,22] or the CN group linked in a conjugate way with a pyridine (Fig. 2 (C and D)) [23, 24].

In addition, a review of the literature allowed to notice that several strongly cytotoxic chemical scaffolds contain in their structures amine (Fig. 2 (E and F)) or cyano (Fig. 2 $(G$ and $H)$ ) groups directly linked to a heterocycle $[25,26]$. This particular structural linkage gave the kick-off to several research teams to design and synthesize amino-pyrimidine and cyano-pyridine scaffolds due to this notable anticancer activity against a wide range of cell lines.

Inspired by the above findings, and in continuation of our previous work on the synthesis of novel fused-pyrimidine scaffolds [27-29] we aimed to design and synthesize new pyrazolo[4,3-e]pyrido[1,2-a]pyrimidine derivatives. Hereby, we are reporting for the first time the cytotoxic activity of these newly synthesized compounds towards five human tumor cell lines, A375, HT29, MCF7, A2780, FaDu as well as non-malignant NIH 3 T3 and HEK293 cells. Moreover, their structure-activity relationship (SAR) was investigated.
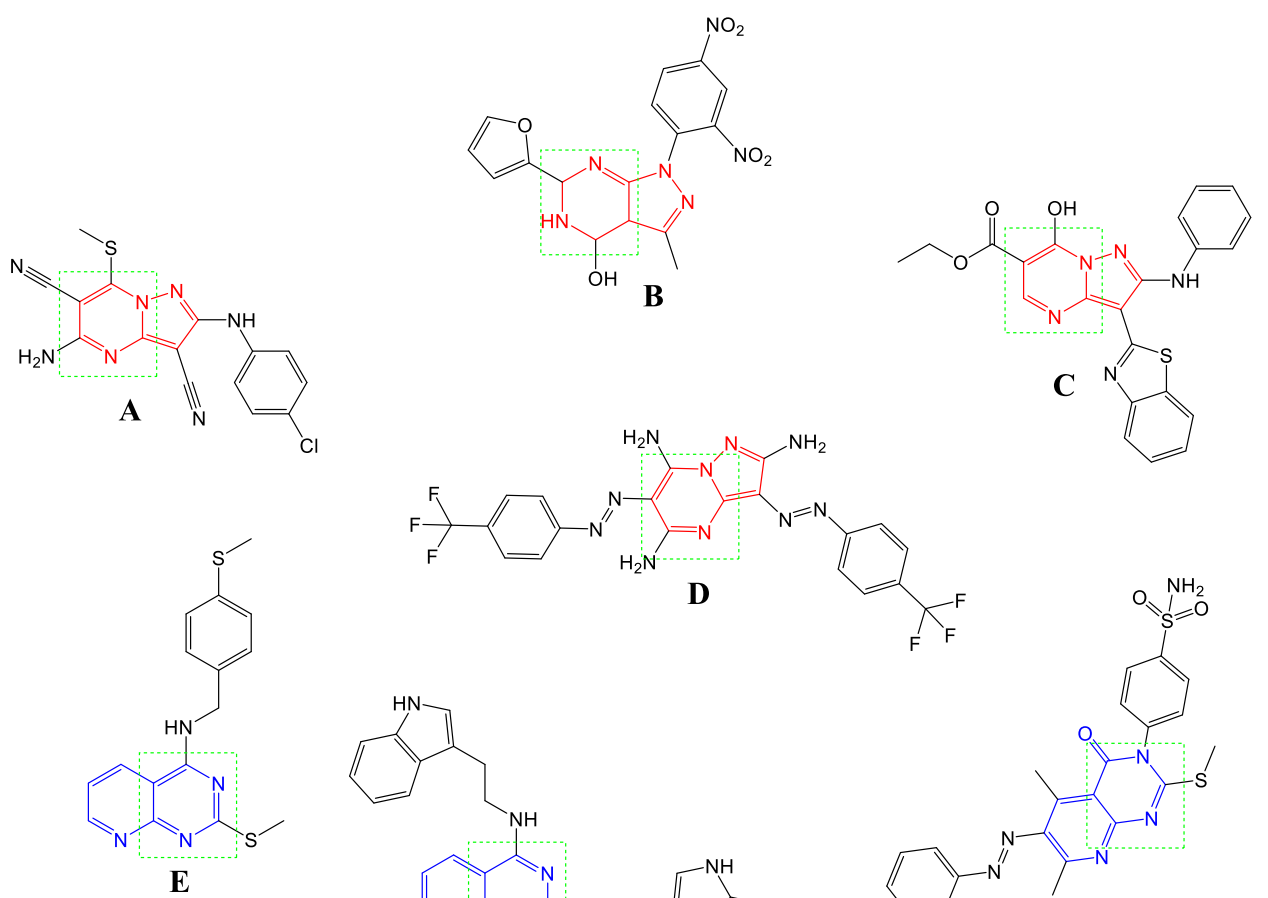

C
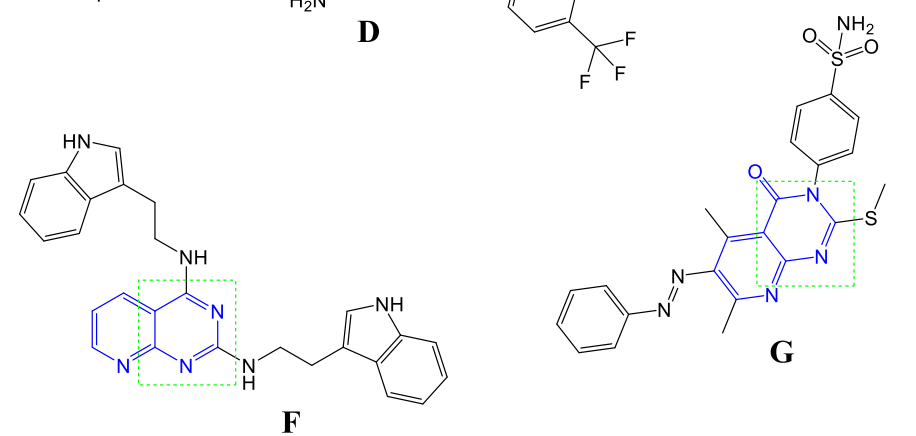
Figure 1. Previously reported cytotoxic compounds: pyrazole-fused pyrimidines (A-D) and pyridine-fused pyrimidines (E-G).

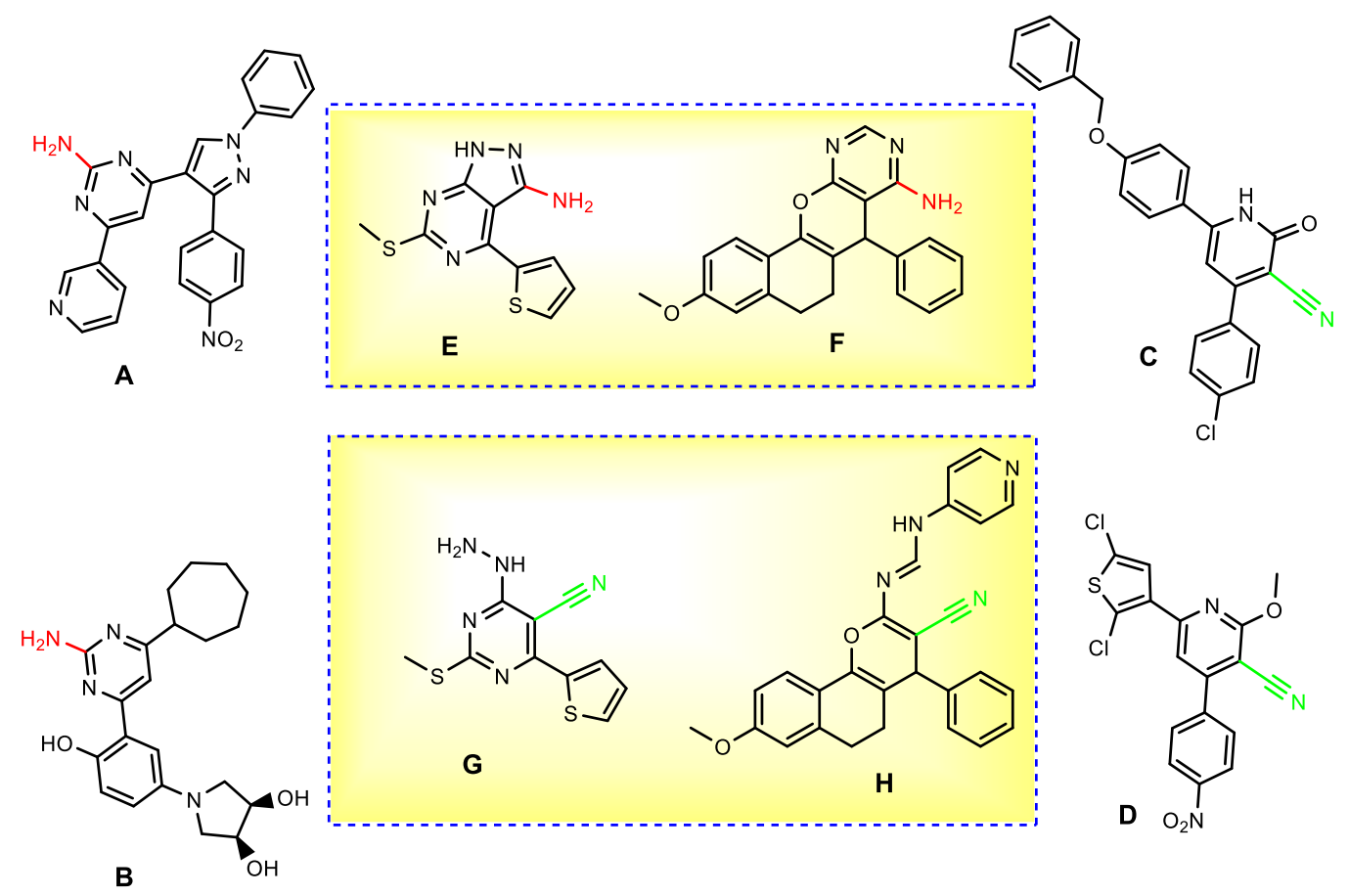

Figure 2. Previously reported cytotoxic compounds tethered with amino or cyano groups.

\section{Results and Discussion}

\subsection{Chemistry}

The multi-step synthesis of target compounds 7a-l (Scheme 1) started from the bi-nucleophilic precursor 3 ; the latter was prepared according to a previously published literature procedure [30] starting from 2-(1-ethoxyethylidene)malononitrile (1) and phenylhydrazine (2). Compound 5, an enaminone holding a pyrazole moiety, was obtained from the nucleophilic addition reaction of 5-amino-3-methyl-1-phenyl-1H-pyrazole-4-carbonitrile (3) and acetylacetone (2,4-pentanedione, 4$)$ in the presence of a catalytic amount of trichloroacetic acid (TCAA) acting as a catalyst under solvent-free conditions. In the next step, cyclo-condensation reactions of 5 and a series of arylidenemalononitriles 6 led to the title polyheterocyclic scaffolds 7a-1 (Scheme 1). 
<smiles>CCOC(C)=C(C)C#N</smiles>

3<smiles>CC(=O)C(C)=O</smiles><smiles>CC(=O)C1=C(C)N2C(=C(C#N)C1Br)N=C(N)c1c(C)nn(-c3ccccc3)c12</smiles>

$7 a-1$

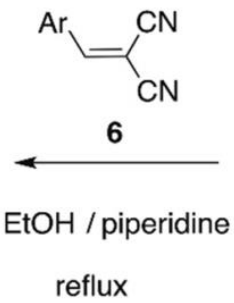

reflux<smiles>CC(=O)/C=C(\C)Nc1c(C)c(C)nn1-c1ccccc1</smiles>

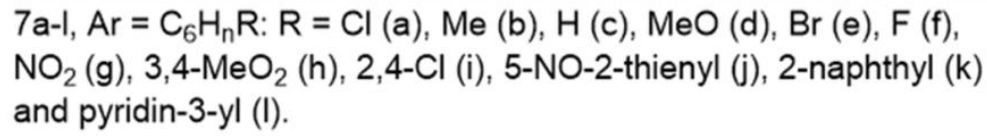

Scheme 1. Synthetic pathway for the synthesis of pyrazolo-pyrido-pyrimidine derivatives 7a-l.

In details, the use of aminopyrazoles as heterocyclizing agents has received considerable attention in recent years. As a result, these molecules have proven to be the building blocks of choice in the preparation of several heterocyclic compounds, they in fact exhibit high reactivity due to the presence of a primary amine function and of a nitrile function in the alpha position. These two functions are capable of reacting as a nucleophilic and electrophilic agent, respectively, and thus subsequently undergo the cyclization reaction. This is why we chose to synthesize this type of amino-cyanopyrazole 3 . Mechanistically, the reaction begins with the attack by the free doublet of the primary amine of phenylhydrazine on the ethylenic quaternary carbon of the ether function in the ethoxyalkylidene 1, releasing an ethanol molecule, then a second nucleophilic attack on the nitrile function by the secondary amine function of the phenylhydrazine leads to the expected pyrazole compound 3 (pathway 1). The lack of access to aminopyrazole $3^{\prime}$ is explained by the low availability of the free nitrogen doublet directly linked to the aromatic moiety (pathway 2) (Scheme 2).

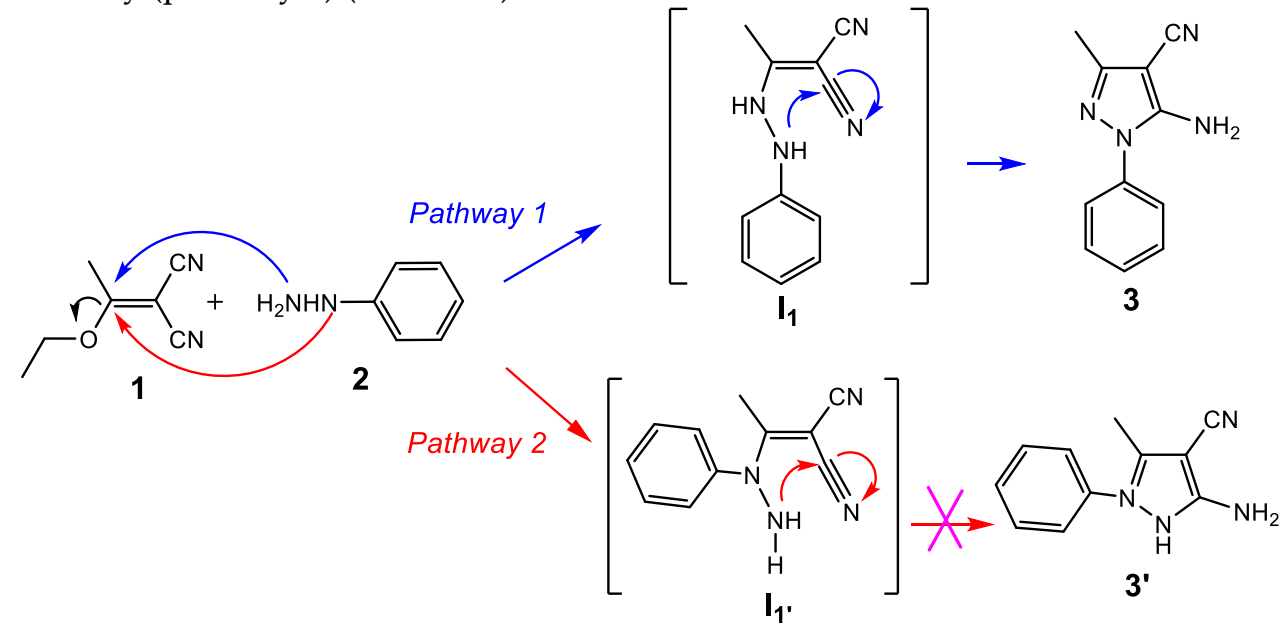


Scheme 2. Plausible mechanistic pathway for the synthesis of target compound $\mathbf{3}$

The use of TCAA ( $\mathrm{pka}=0.77$ ) facilitates the formation of an electrophilic site $(\mathrm{C}=\mathrm{O})$ of the acetylacetone 4 , therefore makes easy the attack of the primary amine's free doublet of the starting building block $\mathbf{3}$ which gives a non-isolable intermediate $\mathbf{I}$. The crucial role of TCAA can be seen again through the facilitation of the dehydration made by a second nucleophilic attack of the free doublet of the same amine function on the same electrophilic site which gives the isolable intermediary 5 (pathway 1 ). This conditions implie the failure to obtain compound 5 ' (pathway 2) (Scheme 3).

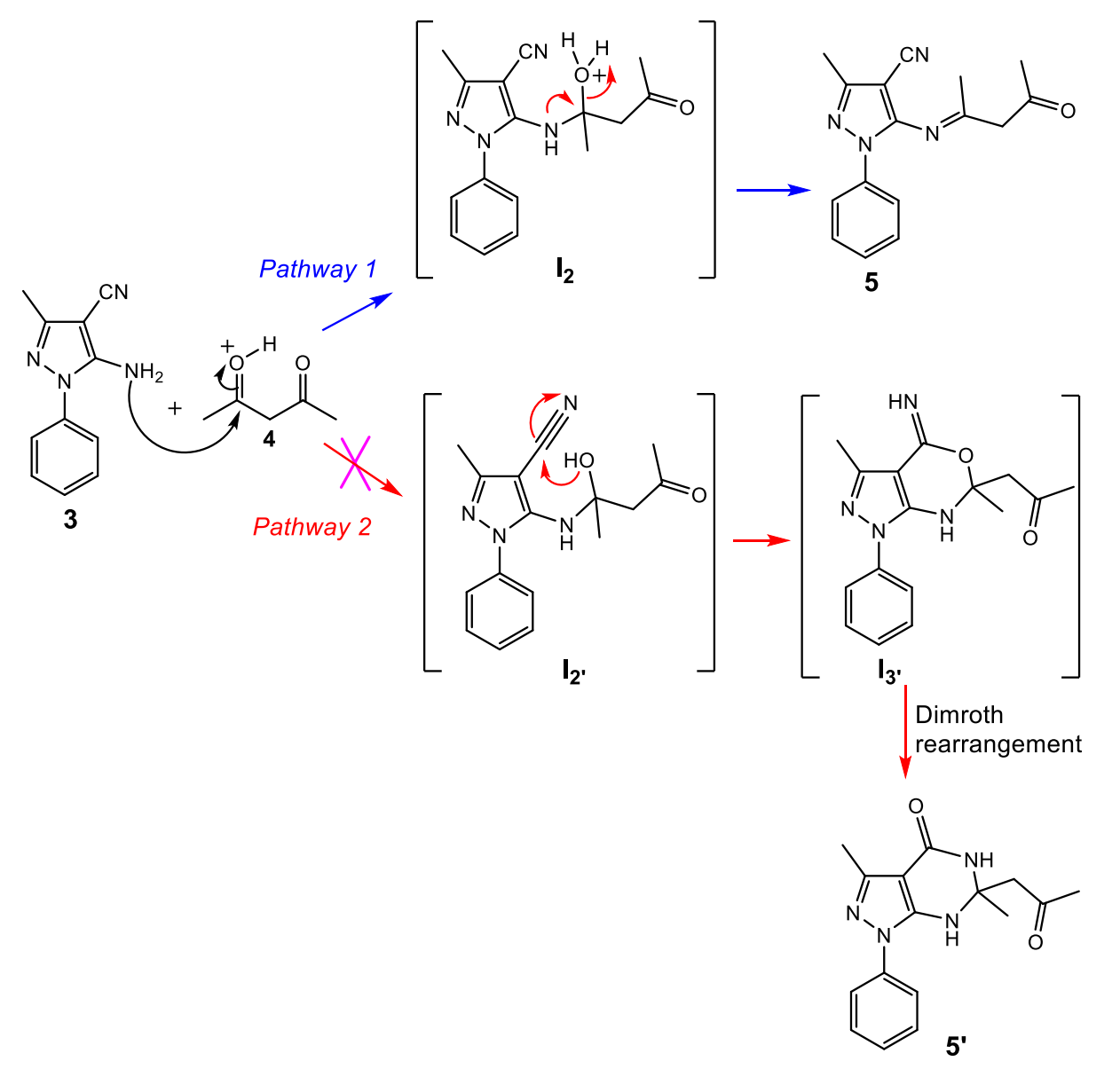

Scheme 3. Plausible mechanistic pathway for the synthesis of compound 5

A putative mechanism (Scheme 4) for the formation of $7 \mathbf{a}-1$ has been depicted in Scheme 2. Thereby, the reaction sequence starts with a nucleophilic attack onto the double bond of the enaminone; this Michael addition forms intermediate $\mathbf{I}_{3}$ which subsequently undergoes a proton transfer from one carbon to another one followed by an intramolecular cyclization to afford the non-isolable intermediate $\mathbf{I}_{5}$. Upon tautomerization a primary amine is formed which attacks the nitrile function of the pyrazole moiety leading finally to target compounds 7 . 

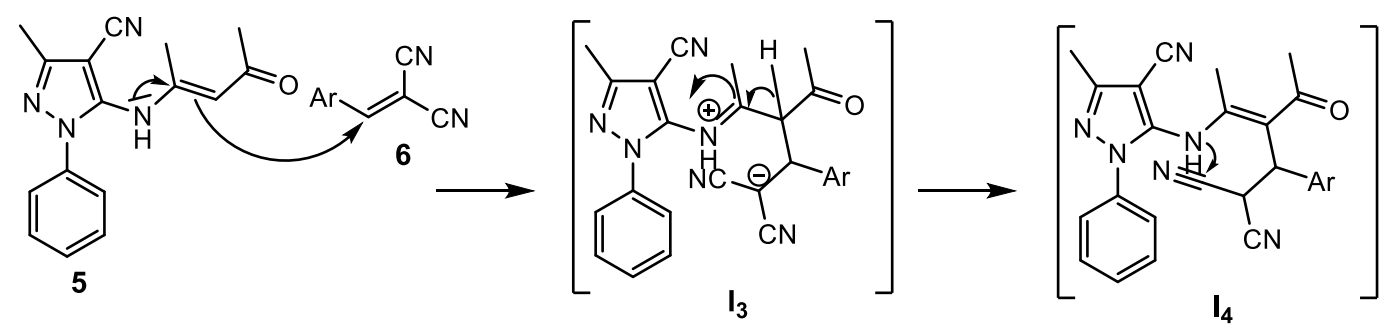<smiles></smiles>
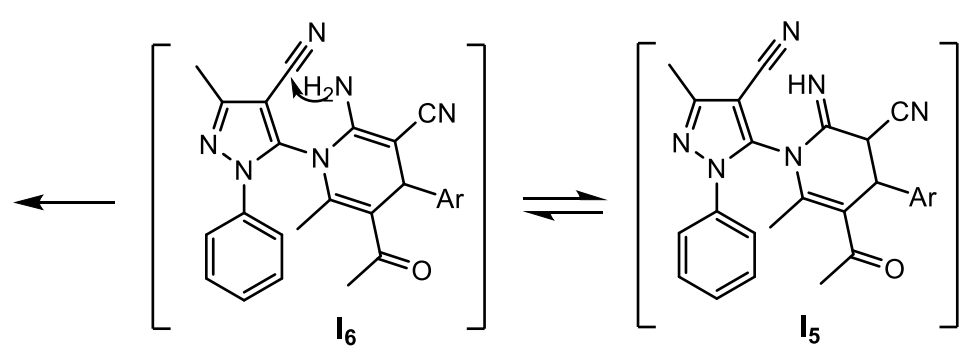

Scheme 4. Putative mechanistic pathway for the synthesis of target compounds $7 \mathbf{a}-\mathbf{I}$.

\subsection{Biological Evaluation}

The synthesized compounds were evaluated for their cytotoxic activity by photometric rhodamine $B$ assay (SRB) on different human cancer cell lines, malignant melanoma (A375), colon (HT29), breast (MCF-7), human ovarian carcinoma (A2780), and pharynx carcinoma $(\mathrm{FaDu})$; for comparison, non-malignant mouse embryonic fibroblasts (NIH 3T3) and human embryonic kidney cells (HEK293) were included; doxorubicin (DX) was used as a positive control [31, 32]. The results are summarized in Table 1.The $\mathrm{EC}_{50}$ values in $\mu \mathrm{M}$ from SRB assays were determined after $72 \mathrm{~h}$ of treatment, and the values are averaged from three independent experiments performed each in triplicate, confidence interval $\mathrm{CI}=95 \%$; mean \pm standard mean error).

Table 1. Cytotoxicity of compounds 3,5, 7a-71 against the human cancer cell lines A375, HT29, MCF-7, A2780, FaDu, and non-malignant cells NIH 3T3 and HEK293 (n.d. not determined, n.s. not soluble under the conditions of the assay).

\begin{tabular}{cccccccc}
\hline Compound & A375 & HT29 & MCF-7 & A2780 & FaDu & NIH 3T3 & HEK293 \\
\hline $\mathbf{3 , 5}$ & $>30$ & $>30$ & $>30$ & $>30$ & $>30$ & $>30$ & $>30$ \\
$\mathbf{7 a}$ & $19.3 \pm 3.0$ & $29.9 \pm 1.4$ & $17.2 \pm 1.4$ & $18.0 \pm 3.0$ & $>30$ & $23.0 \pm 1.4$ & $15.8 \pm 2.0$ \\
$\mathbf{7 b}$ & $12.9 \pm 1.6$ & $17.5 \pm 1.8$ & $12.2 \pm 1.3$ & $14.6 \pm 2.2$ & $22.3 \pm 2.7$ & $21.3 \pm 0.9$ & $12.4 \pm 0.9$ \\
$\mathbf{7 c}$ & $19.3 \pm 3.8$ & $>30$ & $19.5 \pm 1.1$ & $25.4 \pm 2.5$ & $>30$ & $>30$ & $7.7 \pm 1.1$ \\
$\mathbf{7 d}$ & $21.5 \pm 3.6$ & $28.3 \pm 3.5$ & $18.4 \pm 2.3$ & $21.7 \pm 3.9$ & $>30$ & $>30$ & $16.7 \pm 1.2$ \\
$\mathbf{7 e}$ & $9.4 \pm 1.2$ & $13.3 \pm 1.8$ & $9.2 \pm 0.7$ & $9.1 \pm 1.6$ & $13.5 \pm 1.5$ & $12.3 \pm 0.7$ & $6.6 \pm 0.6$ \\
$\mathbf{7 f}$ & $18.1 \pm 3.3$ & $24.7 \pm 4.4$ & $19.2 \pm 1.3$ & $19.2 \pm 3.9$ & $>30$ & $24.1 \pm 2.8$ & $14.7 \pm 1.4$ \\
$\mathbf{7 g}$ & $16.2 \pm 2.0$ & $25.9 \pm 3.4$ & $15.7 \pm 2.2$ & $14.5 \pm 2.2$ & $>30$ & $>30$ & $17.0 \pm 1.3$ \\
$\mathbf{7 h}$ & $22.1 \pm 4.9$ & $>30$ & $25.1 \pm 2.8$ & $27.5 \pm 8.1$ & $>30$ & $>30$ & $24.0 \pm 3.4$ \\
$\mathbf{7 i - 1}$ & n.s. & n.s. & n.s. & n.s. & n.s. & n.s. & n.s. \\
$\mathbf{D X}$ & n.d. & $0.9 \pm 0.01$ & $1.1 \pm 0.3$ & $0.01 \pm 0.01$ & n.d. & $0.4 \pm 0.07$ & n.d. \\
\hline
\end{tabular}

The intermediates 3 and 5 were found to be non-cytotoxic $\left(\mathrm{EC}_{50}>30 \mu \mathrm{M}\right)$ against all the five cancer cell lines. However, many of the target compounds (7a-7h) showed noteworthy cytotoxic effects for all tested human tumor cell lines. 
Our target compounds 7 hold five cyclic rings, A, B, C, D and E (Fig. 3). The values of EC50 differ by the group linked to cycle E. Interestingly, the highest activity in A375 cancer cell was determined for compound 7e with a bromine substituent attached to the aryl moiety E in para position. The next molecule in this series was methyl substituted compound $7 \mathbf{b}$ also exhibiting good cytotoxicity $\left(\mathrm{EC}_{50}=12.9 \pm 1.6 \mu \mathrm{M}\right)$ while nitro-substituted compound $7 \mathrm{~g}$ was less cytotoxic $\left(\mathrm{EC}_{50}=16.2 \pm 2.0 \mu \mathrm{M}\right)$ followed by $7 \mathbf{f}, 7 \mathbf{a}$ and 7c, respectively. On the other hand, the topmost activity in colon cancer cells (HT29) was again determined for $7 \mathbf{e}$ holding an $\mathrm{EC}_{50}$ value of $13.3 \pm 1.8 \mu \mathrm{M}$, followed by $7 \mathbf{b}, 7 \mathbf{f}$ $(\mathrm{Ar}=4-\mathrm{F}-\mathrm{Ph})$ and $7 \mathrm{~g}$ with $\mathrm{EC}_{50}$ values of $17.5 \pm 1.8,24.7 \pm 4.4,25.9 \pm 3.4 \mu \mathrm{M}$, respectively. Towards MCF-7, it is apparent that the same derivative 7e exhibited the highest activity with an $\mathrm{EC}_{50}$ value of $9.2 \pm 0.7 \mu \mathrm{M}$, and compounds $7 \mathbf{b}$ and $7 \mathrm{~g}\left(\mathrm{EC}_{50}=12.2 \pm 1.3,15.7 \pm 2.2\right.$ $\mu \mathrm{M})$ also exhibited good activities.

The highest cytotoxicity for A2780 cancer cell lines was found again for compound $7 \mathbf{e}\left(\mathrm{EC}_{50}=9.1 \pm 1.6 \mu \mathrm{M}\right)$. In this series, compounds $7 \mathbf{g}$ and $7 \mathbf{b}\left(\mathrm{EC}_{50}=14.5 \pm 2.2,14.6 \pm 2.2\right.$ $\mu \mathrm{M}$ ) showed noteworthy activity as compared to other analogs, and their EC 50 values ranged between $18.0 \pm 3.0$ to $27.5 \pm 8.1 \mu \mathrm{M}$. Unfortunately, compound $7 \mathrm{e}$ also showed significant cytotoxic effects for the non-malignant cell lines.

Since the SRB assays showed 7e as the most active compound, molecular docking was performed to establish some structure-activity relationships (SAR). The increase in the activity of $7 \mathbf{e}$ might be due to the presence of an electron-withdrawing group attached to the E ring.

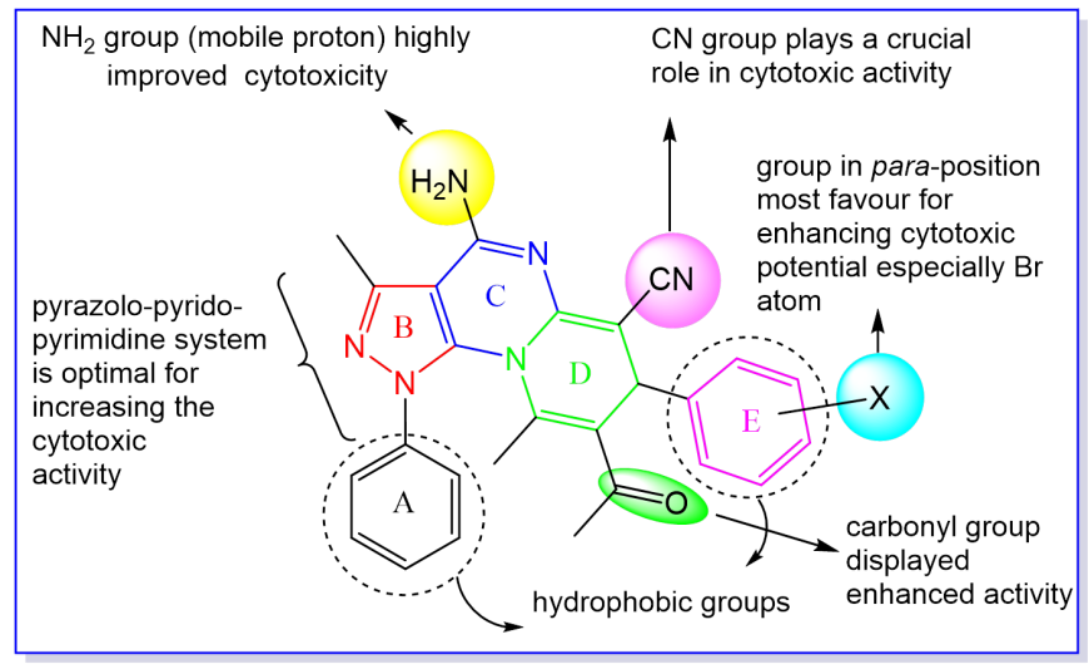

Figure 3. The structure-activity relationship (SAR) of designed scaffolds cytotoxic agents 7.

To develop a new generation of more potent multi-targeted anticancer agents and motivated by previous research on that topic [28, 32, 33], we took advantage of the reported structure activity relationships (SAR) of pyrazolo-pyrido-pyrimidine analogs. Thus, in order to assess the ability of the top-ranked active compounds to inhibit of six anti-cancer drug targets (DHFR, VEGFR2, HER-2/neu, hCA-IX, CDK6 and LOX), we carried out docking study for complexes consisting of compound 7e and the target proteins. This ligand fit very well in the active site binding cavity of all target enzymes (Fig. $4)$. 


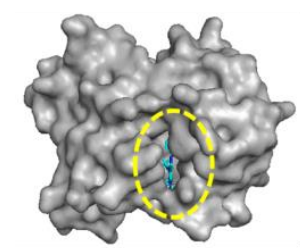

A

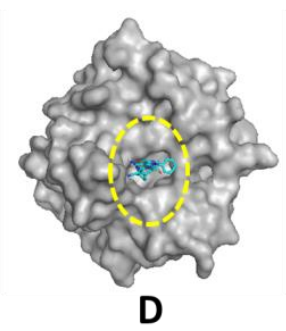

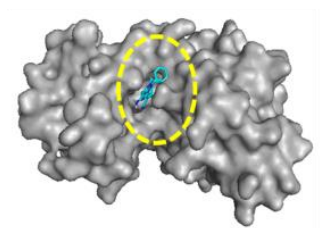

B

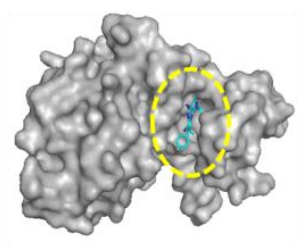

E

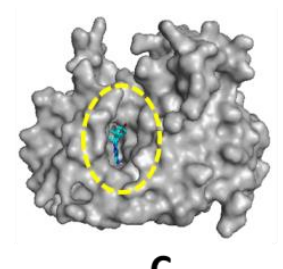

C

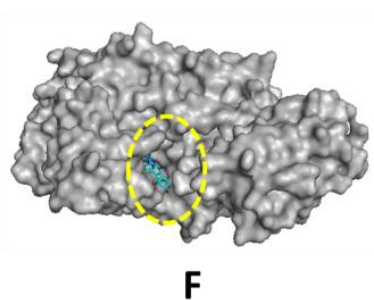

Figure 4. The surface representation of enzyme of pdb: 5HQY (A), 5EW3 (B), 3RCD (C), 5FL4 (D), 3NUP (E) and 3V99 (F) in grey color and the sticks representation (cyan color) of the docked compound 7 e .

The obtained results showed excellent interaction with all the above targets as compared to their respective co-crystallized ligands (Table 2).

Table 2. Free binding energy (Kcal.mol-1) of top-ranked active compound 7e with the active site of different anti-cancer drug targets studied using Autodock 4.2 software.

\begin{tabular}{ccccccc}
\hline \multirow{3}{*}{ Compound } & \multicolumn{6}{c}{ Free binding energy (Kcal.mol-1) } \\
\cline { 2 - 7 } & DHFR & VEGFR2 & HER-2 & hCA-IX & CDK6 & LOX5 \\
& $(5 H Q Y)$ & (5EW3) & $(3 R C D)$ & $(5 F L 4)$ & $(3 N U P)$ & $(3 V 99)$ \\
\hline $7 \mathbf{7}$ & -8.5 & -6.6 & -7.3 & -7.2 & -7.1 & -8.5 \\
Ref. ligand & -8.3 & -7.3 & -7.2 & -7.0 & -6.8 & -6.0 \\
\hline
\end{tabular}

Considering interactions with all the targets under observation, ligand $7 \mathbf{e}$ fits well inside the pocket; it displayed crucial hydrogen bonds by its $(\mathrm{CO})$ and $\left(\mathrm{NH}_{2}\right)$ groups; thereby in the case of the most favorable complex of compound 7e with DHFR, four H-bonds were formed: three between the amine function and GLY20, ASP21 and SER59 and one through the carbonyl group with THR56. The fused heterocyclic system seems to play a significant binding role through the appearance of pi-sigma interaction with LEU22. In addition, the phenyl groups exhibit many hydrophobic interactions (Fig. 5.A). Moreover, towards active site amino acids of VEGFR2 (Fig. 5.B) 7e is involved in two H-bonds with SER884 and ARG1027, a pi-sigma interaction with ILE888, a pi-sulfur interaction with CYS1024, as well as alkyl with PRO821 and pi-alkyl with LYS 887 and ILE888. Furthermore, in the case of HER-2/neu, compound 7e forms some substantial H-bonds, i.e. two through its amine function and one by its carbonyl group, a pi-sigma interaction with LEU852 besides many hydrophobic interactions with the amino acid sequence VAL734, ALA751, LEU800, MET801 and CYS 805 (Fig. 5.C). In the same manner, towards active site amino acids of hCA-IX, ligand 7e formed a conventional hydrogen bond by its carbonyl group with THR201, showed pi-sigma interaction with LEU199 and hydrophobic interactions with residues HIS68, HIS94, HIS119, VAL121, VAL130, VAL142 and TRP210 (Fig. 5.D). Furthermore, for complex CDK6-7e, a hydrogen bond formed between $\left(\mathrm{NH}_{2}\right)$ and ASP102, pi-anion with ASP104 and hydrophobic interactions with ILE19, VAL27, LEU152 and ALA162 (Fig. 5.E) were found. Finally, against LOX, 7e demonstrated three $\mathrm{H}$-bonds through its $\mathrm{CO}$ and $\mathrm{NH}_{2}$ groups with PHE177 and LEU607 
and showed some hydrophobic interactions with the amino acids sequence PHE177, HIS367, LYS409 and LEU607 (Fig. 5.F).

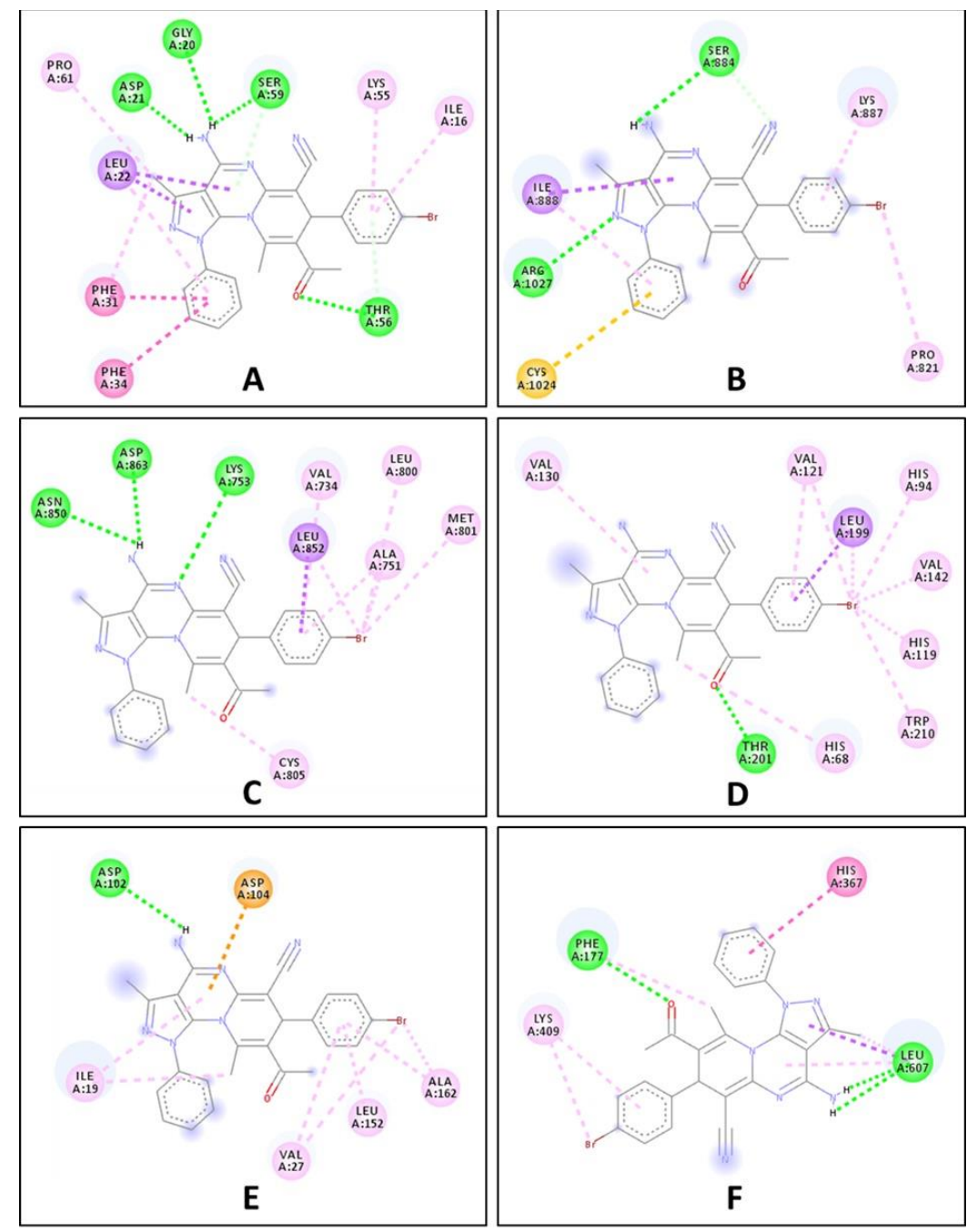

Figure 5. Docking pose (2D binding model) of the most active cytotoxic agent 7e in the active site of DHFR (PDB: 5HQY). (A), VEGFR2 (PDB: 5EW3). (B), HER-2 (PDB: 3RCD). (C), hCA-IX (PDB: 5FL4). (D), CDK6 (PDB: 3NUP). (E) and LOX5 (PDB: 3V99). (F).

\section{Materials and Methods}

\subsection{General}

A detailed description of materials and methods can be found in the supplementary materials file. For molecular docking, the 3D crystal structures of PDB were obtained from the RSCB protein data bank (PDB): DHFR (ID:5HQY[34, 35]), VEGFR2 (ID:5EW3 [34, 36]), HER2/neu (ID:3RCD [34, 37]), hCA-IX (ID:5FL4 [34, 38]), CDK6 (ID:3NUP [34, 39]) and LOX5 (ID:3V99 [34, 40]). All water molecules were removed, and hydrogen atoms were added before docking using discovery studio visualize; Gasteiger charges also were added to the system during the preparation of the receptor input file. Docking studies were performed using AutoDock 4.2 software (Scripps Research; http://autodock.scripps.edu). The structures of the compounds were drawn using ChemDraw [ver. 10.0]. The optimization of all the geometries of scaffolds was performed with ACD (3D viewer) software (http://www.filef acts.com/acd3d-viewer-freeware-info). Co-crystalized ligands in the proteins were taken as reference ligands and re-docked into the active site of proteins for energy comparison. The top-scored conformation was recorded for each compound and used for further analysis and 2D images were captured 
through discovery studio visualizer (2017) developed by Accelrys (BIOvIA, San Diego, USA).${ }^{13} \mathrm{C}$ NMR spectra (Supplementary material) were recorded as APT spectra showing $\mathrm{CH}$ and $\mathrm{CH}_{3}$ groups as positive signals and $\mathrm{CH}_{2}$ groups and quaternary carbons as negative signals.

\subsection{5-Amino-3-methyl-1-phenyl-1H-pyrazole-4-carbonitrile (3)}

To an ice-cold solution of $1(0.1 \mathrm{~mol})$ in ethanol $(100 \mathrm{~mL}), 2(0.1 \mathrm{~mol})$ was added, and the mixture was stirred for $3 \mathrm{~h}$. The precipitate was filtered off and re-crystalized from ethanol; yield: $86 \%$; m.p. $132{ }^{\circ} \mathrm{C}$; $\mathrm{R}_{\mathrm{F}}=0.69\left(\mathrm{SiO}_{2}, \mathrm{CHCl}_{3} / \mathrm{MeOH}, 95: 5\right)$; IR (ATR): $v=3329 \mathrm{~m}$, 2216s, 1652m, 1596m, 1563m, 1533s, 1488m, 1444m, 1318w, 996w, 833w, 758s, 722m, 689s, 624m, 554m, 506m, 451w cm ${ }^{-1}$; ${ }^{1} \mathrm{H}$ NMR (500 MHz, $\left.\mathrm{CDCl}_{3}\right): \delta=7.51-7.47(\mathrm{~m}, 2 \mathrm{H}, 3-\mathrm{H}$, 5-H), 7.47 - 7.43 (m, 2H, 2-H, 6-H), $7.42-7.38$ (m, 1H, 4-H), 4.67 (s, 2H, NH 2$), 2.29$ (s, 3H, 11-H) ppm; ${ }^{13} \mathrm{C}$ NMR (126 MHz, $\left.\mathrm{CDCl}_{3}\right): \delta=151.1$ (C-9), 150.3 (C-7), 137.0 (C-1), 130.0 (C-3, C-5), 128.7 (C-4), 124.2 (C-2, C-6), 114.6 (C-10), 76.3 (C-8), 13.0 (C-11) ppm; MS (ESI, $\mathrm{MeOH}): \mathrm{m} / \mathrm{z} 199\left(100 \%,[\mathrm{M}+\mathrm{H}]^{+}\right), 237\left(52 \%,[\mathrm{M}+\mathrm{K}]^{+}\right)$; analysis calcd for $\mathrm{C}_{11} \mathrm{H}_{10} \mathrm{~N}_{4}(198.22)$ : C 66.65, H 5.09, N 28.26; found: C 66.41, H 5.24, N 28.04.

\subsection{3-Methyl-5-\{[(1E)-1-methyl-3-oxobut-1-en-1-yl]amino\}-1-phenyl-1H-pyrazole-4-carbonitrile} (5)

A mixture of aminopyrazole $3(7 \mathrm{mmol})$, acetylacetone $4(7 \mathrm{mmol})$ and trichloroacetic acid $(1 \mathrm{mmol})$ was stirred at $120^{\circ} \mathrm{C}$ for $10 \mathrm{~h}$. The precipitate was filtered off, dissolved in a minimum amount of $\mathrm{CHCl}_{3}$, and precipitated with petrol ether followed by chromate ographic purification $\left(\mathrm{SiO}_{2}\right.$, chloroform/ethyl acetate, 9:1): yield: 62\%; m.p. $109{ }^{\circ} \mathrm{C}$; $\mathrm{R}_{\mathrm{F}}=$ $0.89\left(\mathrm{SiO}_{2}, \mathrm{CHCl}_{3} / \mathrm{MeOH}, 95: 5\right)$; $\mathrm{UV}-\mathrm{Vis}\left(\mathrm{CHCl}_{3}\right): \lambda \max (\log \varepsilon)=260 \mathrm{~nm}$ (3.96), $308 \mathrm{~nm}$ (3.96); IR (ATR): $v=2228 \mathrm{~m}, 1619 \mathrm{~s}, 1574 \mathrm{~s}, 1503 \mathrm{~m}, 1430 \mathrm{~m}, 1357 \mathrm{w}, 1274 \mathrm{~s}, 1181 \mathrm{w}, 1125 \mathrm{w}$, 1022w, 908w, 790w, 747s, 693s, 636w, 536w, 512s cm ${ }^{-1} ;{ }^{1} \mathrm{H} \mathrm{NMR}\left(500 \mathrm{MHz}, \mathrm{CDCl}_{3}\right): \delta=$ 12.42 (s, 1H, NH), $7.53-7.27$ (m, 5H, 2-H, 3-H, 4-H, 5-H, 6-H), 5.35 (s, 1H, 13-H), 2.43 (s, $3 \mathrm{H}, 11-\mathrm{H}), 2.09(\mathrm{~s}, 3 \mathrm{H}, 15-\mathrm{H}), 1.94(\mathrm{~s}, 3 \mathrm{H}, 16-\mathrm{H}) \mathrm{ppm} ;{ }^{13} \mathrm{C} \mathrm{NMR}\left(126 \mathrm{MHz}, \mathrm{CDCl}_{3}\right): \delta=$ 198.7 (C-14), 158.2 (C-12), 152.4 (C-7), 142.4 (C-9), 137.4 (C-1), 129.9 (C-3, C-5), 129.2 (C-4), 124.3 (C-2, C-6), 113.7 (C-10), 101.3 (C-13), 90.6 (C-8), 29.8 (C-15), 19.7 (C-16), 13.6 (C-11) ppm; MS (ESI, MeOH): m/z $281\left(32 \%,[\mathrm{M}+\mathrm{H}]^{+}\right), 303\left(100 \%,[\mathrm{M}+\mathrm{Na}]^{+}\right)$; analysis calcd for $\mathrm{C}_{16} \mathrm{H}_{16} \mathrm{~N}_{4} \mathrm{O}$ (280.33): C 68.55, H 5,75, N 19.99; found: C 687.37, H 5.98, N 19.75.

\subsection{General procedure for the synthesis of compounds $7 a-l$}

A mixture of enaminone $5(1 \mathrm{mmol})$ and arylidenemalononitrile 6 (1 $\mathrm{mmol})$ was heated at reflux in ethanol $(10 \mathrm{~mL})$ in the presence of a catalytic amount of piperidine for $8 \mathrm{~h}$. The solvent was removed at reduced pressure, and the crude products were purified by chromatography $\left(\mathrm{SiO}_{2}\right.$, chloroform/ethyl acetate, 8/2).

\subsection{8-Acetyl-4-amino-7-(4-chlorophenyl)-3,9-dimethyl-1-phenyl-1,7-dihydropyrazolo[4,3-e] pyrido[1,2-a]pyrimidine-6-carbonitrile (7a)}

Yield: $78 \%$; m.p. $167{ }^{\circ} \mathrm{C}$; $\mathrm{RF}_{\mathrm{F}}=0.33\left(\mathrm{SiO}_{2}, \mathrm{CHCl}_{3} / \mathrm{MeOH}, 95: 5\right) ; \mathrm{UV}-\mathrm{V}$ is $\left(\mathrm{CHCl}_{3}\right): \lambda_{\max }$ $(\log \varepsilon)=290 \mathrm{~nm}(3.97) ;$ IR (ATR): $v=3332 \mathrm{w}, 2185 \mathrm{~m}, 1653 \mathrm{~m}, 1609 \mathrm{~s}, 1570 \mathrm{~m}, 1540 \mathrm{~s}, 1488 \mathrm{~m}$, $1221 \mathrm{~m}, 1192 \mathrm{w}, 1090 \mathrm{w}, 1012 \mathrm{w}, 859 \mathrm{w}, 764 \mathrm{~m}, 693 \mathrm{~m}, 624 \mathrm{w}, 509 \mathrm{~m} \mathrm{~cm}^{-1} ;{ }^{1} \mathrm{H}$ NMR $(500 \mathrm{MHz}$, $\left.\mathrm{CDCl}_{3}\right): \delta=7.37-7.19(\mathrm{~m}, 8 \mathrm{H}, 2-\mathrm{H}, 3-\mathrm{H}, 5-\mathrm{H}, 6-\mathrm{H}, 22-\mathrm{H}, 23-\mathrm{H}, 25-\mathrm{H}, 26-\mathrm{H}), 6.73(\mathrm{~m}, 1 \mathrm{H}$, 4-H), 4.97 (s, 1H, 15-H), 2.61 (s, 3H, 10-H), 2.36 (s, 3H, 19-H), 1.68 (s, 3H, 17-H) ppm; ${ }^{13} \mathrm{C}$ NMR (126 MHz, $\left.\mathrm{CDCl}_{3}\right): \delta=197.9$ (C-18), 147.6 (C-12), 146.2 (C-11), 144.1 (C-7), 143.9 (C-13), 141.4 (C-9), 140.3 (C-21), 138.0 (C-1), 133.7 (C-24), 130.1 (C-3, C-5), 129.2 (C-23, C-25), 129.2 (C-2, C-6), 128.4 (C-22, C-26), 125.5 (C-20), 124.0 (C-14), 123.1 (C-4), 100.0 (C-8), 72.2 (C-16), 40.1 (C-15), 31.0 (C-19), 14.5 (C-10) ppm; MS (ESI, MeOH): m/z 467 $\left(100 \%,[\mathrm{M}-\mathrm{H}]^{-}\right)$; analysis calcd for $\mathrm{C}_{26} \mathrm{H}_{21} \mathrm{ClN} 6 \mathrm{O}$ (468.94): C 66.59, H 4.51, N 17.92; found: C 66.30, H 4.72, N 17.63. 
3.6. 8-Acetyl-4-amino-3,9-dimethyl-7-(4-methylphenyl)-1-phenyl-1,7-dihydropyrazolo[4,3-e] pyrido1,2-a]pyrimidine-6-carbonitrile (7b)

Yield: 66\%; m.p. $167{ }^{\circ} \mathrm{C}$; $\mathrm{RF}_{\mathrm{F}}=0.33\left(\mathrm{SiO}_{2}, \mathrm{CHCl}_{3} / \mathrm{MeOH}, 95: 5\right) ; \mathrm{UV}-\mathrm{V}$ is $\left(\mathrm{CHCl}_{3}\right): \lambda_{\max }$ $(\log \varepsilon)=289 \mathrm{~nm}(4.27) ;$ IR (ATR): $v=2185 \mathrm{~m}, 1608 \mathrm{~s}, 1542 \mathrm{~s}, 1479 \mathrm{~m}, 1449 \mathrm{w}, 1357 \mathrm{w}, 1223 \mathrm{~m}$, $1194 \mathrm{w}, 879 \mathrm{w}, 810 \mathrm{w}, 764 \mathrm{~m}, 695 \mathrm{~m}, 624 \mathrm{w}, 511 \mathrm{~m} \mathrm{~cm}^{-1} ;{ }^{1} \mathrm{H}$ NMR $\left(500 \mathrm{MHz}, \mathrm{CDCl}_{3}\right): \delta=7.33-$ 7.28 (m, 2H, 2-H, 6-H), 7.23 - 7.18 (m, 2H, 3-H, 5-H), 7.17 (s, 4H, 2-H, 3-H, 5-H, 6-H), 6.78 $6.67(\mathrm{~m}, 1 \mathrm{H}, 4-\mathrm{H}), 4.94(\mathrm{~s}, 1 \mathrm{H}, 15-\mathrm{H}), 2.58$ (s, 3H, 10-H), 2.38 (s, 3H, 19-H), 2.32 (s, 3H, 27-H), 1.65 (s, 3H, 17-H) ppm; $\left.{ }^{13} \mathrm{C} \mathrm{NMR} \mathrm{(126} \mathrm{MHz,} \mathrm{CDCl}\right): \delta=197.9(\mathrm{C}-18), 155.8(\mathrm{C}-12)$, 155.0 (C-11), 145.3 (C-7), 143.2 (C-13), 141.2 (C-9), 138.5 (C-21), 137.8 (C-1), 137.0 (C-24), 129.6 (C-3, C-5), 129.2 (C-23, C-25), 128.4 (C-2, C-6), 126.4 (C-22, C-26), 125.1 (C-20), 122.7 (C-4), 122.5 (C-14), 99.8 (C-8), 71.5 (C-16), 40.0 (C-15), 30.3 (C-19), 21.0 (C-27), 19.1 (C-17), 13.7 (C-10) ppm; MS (ESI, MeOH): m/z449 (100\%, [M+H] $\left.]^{+}\right)$; analysis calcd for $\mathrm{C}_{27} \mathrm{H}_{24} \mathrm{~N}_{6} \mathrm{O}$ (448.52): C 72.30, H 5.39, N 18.74; found: C 72.07, H 5.51. N 18.55.

\subsection{8-Acetyl-4-amino-3,9-dimethyl-1,7-diphenyl-1,7-dihydropyrazolo[4,3-e] pyrido[1,2-a]pyrimidine-6-carbonitrile (7c)}

Yield: 62\%; m.p. $198{ }^{\circ} \mathrm{C} ; \mathrm{R}_{\mathrm{F}}=0.31\left(\mathrm{SiO}_{2}, \mathrm{CHCl}_{3} / \mathrm{MeOH}, 95: 5\right) ; \mathrm{UV}-\mathrm{Vis}\left(\mathrm{CHCl}_{3}\right): \lambda_{\max }$ $(\log \varepsilon)=289 \mathrm{~nm}(4.54) ;$ IR (ATR): $v=3148 \mathrm{w}, 2181 \mathrm{~m}, 1660 \mathrm{~m}, 1601 \mathrm{~s}, 1544 \mathrm{~s}, 1480 \mathrm{~m}, 1447 \mathrm{~m}$, $1355 \mathrm{w}, 1220 \mathrm{~m}, 1197 \mathrm{~m}, 878 \mathrm{w}, 764 \mathrm{~m}, 722 \mathrm{~m}, 694 \mathrm{~s}, 627 \mathrm{w}, 511 \mathrm{~s} \mathrm{~cm}{ }^{-1} ;{ }^{1} \mathrm{H}$ NMR $(500 \mathrm{MHz}$, $\left.\mathrm{CDCl}_{3}\right): \delta=7.40-7.16(\mathrm{~m}, 9 \mathrm{H}, 2-\mathrm{H}, 3-\mathrm{H}, 5-\mathrm{H}, 6-\mathrm{H}, 22-\mathrm{H}, 23-\mathrm{H}, 24-\mathrm{H}, 25-\mathrm{H}, 26-\mathrm{H}), 6.73-$ $6.66(\mathrm{~m}, 1 \mathrm{H}, 4-\mathrm{H}), 5.00(\mathrm{~s}, 1 \mathrm{H}, 15-\mathrm{H}), 2.59$ (s, 3H, 10-H), 2.39 (s, 3H, 19-H), 1.65 (s, 3H, 17-H) ppm; ${ }^{13} \mathrm{C}$ NMR (126 MHz, $\left.\mathrm{CDCl}_{3}\right): \delta=198.0$ (C-18), 155.9 (C-12), 155.2 (C-11), 145.5 (C-7), 143.3 (C-13), 141.6 (C-9), 141.3 (C-21), 137.8 (C-1), 129.7 (C-3, C-5), 128.7 (C-23, C-25), 128.5 (C-2, C-6), 127.5 (C-24), 126.6 (C-22, C-26), 125.3 (C-20), 122.7 (C-4), 122.5 (C-14), 100.0 (C-8), 71.3 (C-16), 40.4 (C-15), 30.5 (C-19), 19.2 (C-17), 13.8 (C-10) ppm; MS (ESI, MeOH): m/z435 (100\%, [M+H] $\left.]^{+}\right), 457\left(22 \%,[\mathrm{M}+\mathrm{Na}]^{+}\right)$; analysis calcd for $\mathrm{C}_{26} \mathrm{H}_{22} \mathrm{~N}_{6} \mathrm{O}$ (434.49): C 71.87, H 5.10, N 19.34; found: C 71.66, H 5.29, N 19.07.

\subsection{8-Acetyl-4-amino-7-(4-methoxyphenyl)-3,9-dimethyl-1-phenyl-1,7-dihydropyrazolo[4,3-e] pyrido[1,2-a]pyrimidine-6-carbonitrile (7d)}

Yield: $74 \%$; m.p. $160{ }^{\circ} \mathrm{C} ; \mathrm{R}_{\mathrm{F}}=0.33\left(\mathrm{SiO}_{2}, \mathrm{CHCl}_{3} / \mathrm{MeOH}, 95: 5\right) ; \mathrm{UV}-\mathrm{Vis}\left(\mathrm{CHCl}_{3}\right): \lambda_{\max }$ $(\log \varepsilon)=273 \mathrm{~nm}(4.42) ;$ IR (ATR): $v=2184 \mathrm{~m}, 1607 \mathrm{~s}, 1541 \mathrm{~s}, 1509 \mathrm{~m}, 1478 \mathrm{~m}, 1355 \mathrm{w}, 1249 \mathrm{~m}$, $1174 \mathrm{~m}, 1033 \mathrm{~m}, 825 \mathrm{w}, 764 \mathrm{~m}, 693 \mathrm{~m}, 621 \mathrm{w}, 510 \mathrm{~s} \mathrm{~cm}^{-1} ;{ }^{1} \mathrm{H}$ NMR $\left(500 \mathrm{MHz}, \mathrm{CDCl}_{3}\right): \delta=7.34-$ 7.17 (m, 6H, 2-H, 3-H, 5-H, 6-H, 22-H, 26-H), $6.92-6.87$ (m, 2H, 23-H, 25-H), 6.73 (m, 1H, 4-H), 4.92 (d, J = 1.0 Hz, 1H, 15-H), 3.77 (s, 3H, 27-H), 2.59 (s, 3H, 10-H), 2.38 (s, 3H, 19-H), 1.65 (s, 3H, 17-H) ppm; ${ }^{13} \mathrm{C}$ NMR (126 MHz, CDCl $): \delta=198.1$ (C-18), 159.0 (C-24), 155.7 (C-12), 155.1 (C-11), 145.5 (C-7), 143.2 (C-13), 141.3 (C-9), 137.9 (C-21), 133.5 (C-1), 129.8 (C-3, C-5), 128.6 (C-2, C-6), 127.7 (C-22, C-26), 125.5 (C-20), 122.8 (C-4), 122.5 (C-14), 114.1 (C-23, C-25), 100.0 (C-8), 71.8 (C-16), 55.5 (C-27), 39.8 (C-15), 30.5 (C-19), 19.2 (C-17), 13.8 (C-10) ppm; MS (ESI, MeOH): m/z $465\left(100 \%,[\mathrm{M}+\mathrm{H}]^{+}\right), 487\left(40 \%,[\mathrm{M}+\mathrm{Na}]^{+}\right)$; analysis calcd for $\mathrm{C}_{27} \mathrm{H}_{24} \mathrm{~N}_{6} \mathrm{O}_{2}$ (464.52): C 69.81, H 5.21, N 18.09; found: C 69.57, H 5.41, N 17.84.

\subsection{8-Acetyl-4-amino-7-(4-bromophenyl)-3,9-dimethyl-1-phenyl-1,7-dihydropyrazolo[4,3-e] pyrido[1,2-a]pyrimidine-6-carbonitrile (7e)}

Yield: 75\%; m.p. $192{ }^{\circ} \mathrm{C} ; \mathrm{R}_{\mathrm{F}}=0.40\left(\mathrm{SiO}_{2}, \mathrm{CHCl}_{3} / \mathrm{MeOH}, 95: 5\right) ; \mathrm{UV}-\mathrm{Vis}\left(\mathrm{CHCl}_{3}\right): \lambda_{\max }$ $(\log \varepsilon)=272 \mathrm{~nm}(4.27) ;$ IR (ATR): $v=2186 \mathrm{~m}, 1607 \mathrm{~s}, 1541 \mathrm{~s}, 1485 \mathrm{~m}, 1396 \mathrm{w}, 1357 \mathrm{w}, 1223 \mathrm{~m}$, $1009 \mathrm{~m}, 879 \mathrm{w}, 764 \mathrm{~m}, 694 \mathrm{~m}, 622 \mathrm{w}, 510 \mathrm{~m} \mathrm{~cm}^{-1} ;{ }^{1} \mathrm{H}$ NMR $\left(500 \mathrm{MHz}, \mathrm{CDCl}_{3}\right): \delta=7.49(\mathrm{~d}, \mathrm{~J}=$ $8.5 \mathrm{~Hz}, 2 \mathrm{H}, 23-\mathrm{H}, 25-\mathrm{H}), 7.32(\mathrm{~d}, \mathrm{~J}=7.4 \mathrm{~Hz}, 2 \mathrm{H}, 2-\mathrm{H}, 6-\mathrm{H}), 7.22$ (d, J = 7.8 Hz, 2H, 3-H, 5-H), $7.16(\mathrm{~d}, \mathrm{~J}=8.5 \mathrm{~Hz}, 2 \mathrm{H}, 22-\mathrm{H}, 26-\mathrm{H}), 6.70(\mathrm{~d}, \mathrm{~J}=7.7 \mathrm{~Hz}, 1 \mathrm{H}, 4-\mathrm{H}), 4.94(\mathrm{~s}, 1 \mathrm{H}, 15-\mathrm{H}), 2.58$ (s, $3 \mathrm{H}, 10-\mathrm{H}), 2.36(\mathrm{~s}, 3 \mathrm{H}, 19-\mathrm{H}), 1.67(\mathrm{~s}, 3 \mathrm{H}, 17-\mathrm{H}) \mathrm{ppm} ;{ }^{13} \mathrm{C} \mathrm{NMR}\left(126 \mathrm{MHz}, \mathrm{CDCl}_{3}\right): \delta=$ 197.7 (C-18), 156.1 (C-12), 155.3 (C-11), 145.5 (C-7), 143.7 (C-13), 141.2 (C-21), 140.9 (C-9), 137.8 (C-1), 131.7 (C-23, C-25), 129.8 (C-3, C-5), 128.8 (C-2, C-6), 128.5 (C-22, C-26), 125.0 (C-20), 122.7 (C-14), 122.4 (C-4), 121.3 (C-24), 100.1 (C-8), 70.9 (C-16), 39.9 (C-15), 30.7 
(C-19), 19.3 (C-17), 13.8 (C-10) ppm; MS (ESI, MeOH): m/z 513 (100\%, [M+H] $]^{+}$); analysis calcd for $\mathrm{C}_{26} \mathrm{H}_{21} \mathrm{BrN}_{6} \mathrm{O}$ (512.39): C 60.83, H 4.12, N 16.37; found: C 60.59, H 4.30, N 16.19.

3.10. 8-Acetyl-4-amino-7-(4-fluorophenyl)-3,9-dimethyl-1-phenyl-1,7-dihydropyrazolo[4,3-e] pyrido[1,2-a]pyrimidine-6-carbonitrile ( $7 f)$

Yield: $80 \%$; m.p. $259{ }^{\circ} \mathrm{C}$; $\mathrm{R}_{\mathrm{F}}=0.38\left(\mathrm{SiO}_{2}, \mathrm{CHCl}_{3} / \mathrm{MeOH}, 95: 5\right) ; \mathrm{UV}-\mathrm{Vis}\left(\mathrm{CHCl}_{3}\right): \lambda_{\max }$ $(\log \varepsilon)=273 \mathrm{~nm}(4.31), 289 \mathrm{~nm}(4.30) ;$ IR (ATR): $v=2185 \mathrm{~m}, 1610 \mathrm{~s}, 1542 \mathrm{~s}, 1478 \mathrm{~m}, 1357 \mathrm{w}$, 1223s, 1158m, 1013w, 862w, 764m, 695m, 623w, 513m cm ${ }^{-1} ;{ }^{1} \mathrm{H}$ NMR (500 MHz, $\left.\mathrm{CDCl}_{3}\right): \delta$ $=7.32(\mathrm{t}, \mathrm{J}=7.5 \mathrm{~Hz}, 2 \mathrm{H}, 2-\mathrm{H}, 6-\mathrm{H}), 7.29-7.18(\mathrm{~m}, 4 \mathrm{H}, 22-\mathrm{H}, 23-\mathrm{H}, 25-\mathrm{H}, 26-\mathrm{H}), 7.06(\mathrm{t}, \mathrm{J}=$ $8.6 \mathrm{~Hz}, 2 \mathrm{H}, 3-\mathrm{H}, 5-\mathrm{H}), 6.72(\mathrm{~d}, \mathrm{~J}=7.2 \mathrm{~Hz}, 1 \mathrm{H}, 4-\mathrm{H}), 4.96(\mathrm{~s}, 1 \mathrm{H}, 15-\mathrm{H}), 2.59$ (s, 3H, 10-H), 2.37 (s, 3H, 19-H), $1.66(\mathrm{~s}, 3 \mathrm{H}, 17-\mathrm{H}) \mathrm{ppm} ;{ }^{13} \mathrm{C}$ NMR (126 MHz, CDCl 3$): \delta=197.6(\mathrm{C}-18)$, 161.9 (d, J = 246.6 Hz C-24), 155.8 (C-12), 155.0 (C-11), 145.3 (C-7), 143.2 (C-13), 141.0 (C-9), 137.6 (C-1), 137.2 (d, J = 3.,1 Hz, C-21), 129.5 (C-3, C-5), 128.4 (C-2, C-6), 128.0 (d, J = 7.9 Hz, C-22, C-26), 128.0 (22, 26), 125.1 (C-20), 122.4 (C-14), 122.2 (C-4), 115.3 (d, J = 21.4 Hz, C-23, C-25), 99.8 (C-8), 71.0 (C-16), 39.5 (C-15), 30.4 (C-19), 19.0 (C-17), 13.5 (C-10) ppm; MS (ESI, MeOH): m/z $453\left(100 \%,[\mathrm{M}+\mathrm{H}]^{+}\right), 475\left(22 \%,[\mathrm{M}+\mathrm{Na}]^{+}\right)$; analysis calcd for $\mathrm{C}_{26} \mathrm{H}_{21} \mathrm{FN}_{6} \mathrm{O}$ (452.48): C 69.01, H 4.68,N 18.57; found: C 68.84, H 4.83, N 18.25.

\subsection{8-Acetyl-4-amino-3,9-dimethyl-7-(4-nitrophenyl)-1-phenyl-1,7-dihydropyrazolo[4,3-e] pyrido[1,2-a]pyrimidine-6-carbonitrile (7g)}

Yield: $58 \%$; m.p. $164{ }^{\circ} \mathrm{C}$; $\mathrm{RF}=0.31\left(\mathrm{SiO}_{2}, \mathrm{CHCl}_{3} / \mathrm{MeOH}, 95: 5\right)$; UV-Vis $\left(\mathrm{CHCl}_{3}\right): \lambda_{\max }$ $(\log \varepsilon)=270 \mathrm{~nm}(4.20)$; IR (ATR): $v=2187 \mathrm{~m}, 1608 \mathrm{~s}, 1570 \mathrm{~m}, 1542 \mathrm{~s}, 1519 \mathrm{~m}, 1477 \mathrm{~m}, 1450 \mathrm{w}$, 1344s, 1224m, 1191w, 1013w, 873w, 856w, 763m, 727w, 695m, 622w, 510 $\mathrm{mcm}^{-1}$; ${ }^{1} \mathrm{H}$ NMR $\left(500 \mathrm{MHz}_{\mathrm{CDCl}}\right): \delta=8.23(\mathrm{~d}, \mathrm{~J}=8.8 \mathrm{~Hz}, 2 \mathrm{H}, 23-\mathrm{H}, 25-\mathrm{H}), 7.48(\mathrm{~d}, \mathrm{~J}=8.2 \mathrm{~Hz}, 2 \mathrm{H}, 22-\mathrm{H}$, 26-H), 7.34 (t, J = 7.5 Hz, 2H, 2-H, 6-H), 7.20 (t, J = 7.8 Hz, 2H, 3-H, 5-H), 6.68 (d, J = 7.5 Hz, 1H, 4-H), 5.11 (s, 1H. 15-H), 2.58 (s, 3H, 10-H), 2.37 (s, 3H, 19-H), 1.70 (s, 3H, 17-H) ppm; ${ }^{13} \mathrm{C}$ NMR (126 MHz, $\left.\mathrm{CDCl}_{3}\right): \delta=197.2$ (C-18), 156.5 (C-12), 155.4 (C-11), 149.6 (C-21), 147.3 (C-24), 145.6 (C-7), 144.3 (C-13), 141.1 (C-9), 137.8 (C-1), 129.7 (C-3, C-5), 128.9 (C-2, C-6), 127.8 (C-22, C-26), 124.7 (C-20), 123.9 (C-23, C-25), 122.6 (C-14), 122.1 (C-4), 100.2 (C-8), 70.4 (C-16), 40.3 (C-15), 30.9 (C-19), 19.4 (C-17), 13.8 (C-10) ppm; MS (ESI, MeOH): m/z $480\left(100 \%,[\mathrm{M}+\mathrm{H}]^{+}\right), 502\left(28 \%,[\mathrm{M}+\mathrm{Na}]^{+}\right)$; analysis calcd for $\mathrm{C}_{26} \mathrm{H}_{21} \mathrm{~N}_{7} \mathrm{O}_{3}$ (479.49): C 65.13, $\mathrm{H}$ 4.41, N 20.45; found: C 64.97, H 4.68, N 20.22.

3.12. 8-Acetyl-4-amino-7-(3,4-dimethoxyphenyl)-3,9-dimethyl-1-phenyl-1,7-dihydropyrazolo [4,3-e] pyrido[1,2-a]pyrimidine-6-carbonitrile (7h)

Yield: $72 \%$; m.p. $260{ }^{\circ} \mathrm{C} ; \mathrm{R}_{\mathrm{F}}=0.33\left(\mathrm{SiO}_{2}, \mathrm{CHCl}_{3} / \mathrm{MeOH}, 95: 5\right) ; \mathrm{UV}-\mathrm{Vis}\left(\mathrm{CHCl}_{3}\right): \lambda_{\max }$ $(\log \varepsilon)=286 \mathrm{~nm}(4.23)$; IR (ATR): $v=2185 \mathrm{~m}, 1607 \mathrm{~s}, 1542 \mathrm{~s}, 1514 \mathrm{~s}, 1478 \mathrm{~m}, 1253 \mathrm{~s}, 1236 \mathrm{~s}$, $1137 \mathrm{~m}, 1025 \mathrm{~m}, 874 \mathrm{w}, 813 \mathrm{w}, 764 \mathrm{~m}, 695 \mathrm{~m}, 628 \mathrm{w}, 511 \mathrm{~m} \mathrm{~cm}^{-1} ;{ }^{1} \mathrm{H}$ NMR $\left(500 \mathrm{MHz}, \mathrm{CDCl}_{3}\right): \delta$ $=7.32-7.26(\mathrm{~m}, 2 \mathrm{H}, 2-\mathrm{H}, 6-\mathrm{H}), 7.20(\mathrm{t}, \mathrm{J}=7.8 \mathrm{~Hz}, 2 \mathrm{H}, 3-\mathrm{H}, 5-\mathrm{H}), 6.91-6.61(\mathrm{~m}, 4 \mathrm{H}, 4-\mathrm{H}$, 22-H, 23-H, 26-H), 4.92 (s, 1H, 15-H), 3.87 (s, 3H, 28-H), 3.83 (s, 3H, 27-H), 2.58 (s, 3H, 10-H), 2.38 (s, 3H, 19-H), $1.66(\mathrm{~s}, 3 \mathrm{H}, 17-\mathrm{H})$ ppm; ${ }^{33} \mathrm{C} \mathrm{NMR}\left(126 \mathrm{MHz}, \mathrm{CDCl}_{3}\right): \delta=198.4$ (C-18), 156.3 (C-12), 155.4 (C-11), 149.7 (C-25), 148.9 (C-24), 145.6 (C-7), 143.4 (C-13), 141.6 (C-9), 138.2 (C-1), 134.5 (C-21), 129.9 (C-3, C-5), 128.9 (C-2, C-6), 125.8 (C-20), 123.0 (C-14), 122.8 (C-4), 118.4 (C-22), 111.1 (C-23), 110.9 (C-26), 100.3 (C-8), 71.9 (C-16), 56.5 (C-27, C-28), 40.3 (C-15), 30.8 (C-19), 19.4 (C-17), 14.0 (C-10) ppm; MS (ESI, MeOH): m/z 495 $\left(100 \%,[\mathrm{M}+\mathrm{H}]^{+}\right), 517\left(82 \%,[\mathrm{M}+\mathrm{Na}]^{+}\right)$; analysis calcd for $\mathrm{C}_{28} \mathrm{H}_{26} \mathrm{~N}_{6} \mathrm{O}_{3}$ (494.55): C 68.00, $\mathrm{H}$ 5.30, N 16.99; found: C 67.81, H 5.48, N 16.72.

3.13. 8-Acetyl-4-amino-7-(3,4-dichlorophenyl)-3,9-dimethyl-1-phenyl-1,7-dihydropyrazolo[4,3-e Ipyrido[1,2-a]pyrimidine-6-carbonitrile (7i)

Yield: $70 \%$; m.p. $235{ }^{\circ} \mathrm{C}$; $\mathrm{R}_{\mathrm{F}}=0.36\left(\mathrm{SiO}_{2}, \mathrm{CHCl}_{3} / \mathrm{MeOH}, 95: 5\right) ; \mathrm{UV}-\mathrm{Vis}\left(\mathrm{CHCl}_{3}\right): \lambda_{\max }$ $(\log \varepsilon)=262 \mathrm{~nm}(4.29), 289 \mathrm{~nm}(4.25) ;$ IR (ATR): $v=2183 \mathrm{~m}, 1685 \mathrm{~m}, 1600 \mathrm{~s}, 1543 \mathrm{~s}, 1474 \mathrm{~m}$, $1382 \mathrm{w}, 1353 \mathrm{~m}, 1221 \mathrm{~m}, 1183 \mathrm{w}, 1043 \mathrm{w}, 956 \mathrm{w}, 864 \mathrm{~m}, 822 \mathrm{w}, 770 \mathrm{~m}, 695 \mathrm{~m}, 627 \mathrm{~m}, 512 \mathrm{~s} \mathrm{~cm}^{-1}$; ${ }^{1} \mathrm{H}$ NMR (500 MHz, $\left.\mathrm{CDCl}_{3}\right): \delta=7.52(\mathrm{~d}, \mathrm{~J}=2.0 \mathrm{~Hz}, 1 \mathrm{H}, 25-\mathrm{H}), 7.31-7.28(\mathrm{~m}, 2 \mathrm{H}, 3-\mathrm{H}, 5-\mathrm{H})$, 
7.21 - 7.12 (m, 4H, 2-H, 6-H, 22-H, 23-H), 6.64 (d, J = 7.5 Hz, 1H, 4-H), 5.03 (s, 1H, 15-H), 2.61 (s, 3H, 10-H), 2.42 (s, 3H, 19-H), 1.50 (s, 3H, 17-H) ppm; $\left.{ }^{13} \mathrm{C} \mathrm{NMR} \mathrm{(126} \mathrm{MHz,} \mathrm{CDCl}\right)$ : $\delta=198.7$ (C-18), 157.2 (C-12), 155.3 (C-11), 145.6 (C-7), 141.4 (C-9), 140.5 (C-13), 137.7 (C-1), 136.0 (C-21), 134.7 (C-26), 134.3 (C-24), 130.6 (C-25), 129.7 (C-2, C-6), 129.3 (C-22), 128.9 (C-3, C-5), 127.1 (C-23), 125.0 (C-20), 122.4 (C-4), 121.6 (C-14), 99.8 (C-8), 68.8 (C-16), 40.3 (C-15), 29.9 (C-19), 18.4 (C-17), 13.9 (C-10) ppm; MS (ESI, MeOH): m/z 503 (100\%, $\left.[\mathrm{M}+\mathrm{H}]^{+}\right), 525\left(42 \%,[\mathrm{M}+\mathrm{Na}]^{+}\right)$; analysis calcd for $\mathrm{C}_{26} \mathrm{H}_{20} \mathrm{Cl}_{2} \mathrm{~N}_{6} \mathrm{O}(502.38): \mathrm{C} 62.04, \mathrm{H} 4.00, \mathrm{~N}$ 16.70; found: C 61.87, H 45.29, N 16.52.

\subsection{8-Acetyl-4-amino-3,9-dimethyl-7-(5-nitro-2-thienyl)-1-phenyl-1,7-dihydropyrazolo[4,3-e]} pyrido[1,2-a]pyrimidine-6-carbonitrile (7j)

Yield: $74 \%$; m.p. $262{ }^{\circ} \mathrm{C}$; $\mathrm{RF}=0.60\left(\mathrm{SiO}_{2}, \mathrm{CHCl}_{3} / \mathrm{MeOH}, 95: 5\right) ; \mathrm{UV}-\mathrm{Vis}\left(\mathrm{CHCl}_{3}\right): \lambda_{\max }$ $(\log \varepsilon)=328 \mathrm{~nm}(3.86) ;$ IR (ATR): $v=3434 \mathrm{~m}, 2237 \mathrm{~m}, 2195 \mathrm{~s}, 1688 \mathrm{~m}, 1650 \mathrm{~s}, 1578 \mathrm{w}, 1549 \mathrm{~m}$, 1494s, 1420s, 1333s, 1262m, 1197m, 1112w, 955w, 816m, 759m, 688m, 660m, 635m, 562m, $510 \mathrm{~m} \mathrm{~cm}^{-1}$; ${ }^{1} \mathrm{H}$ NMR $\left(500 \mathrm{MHz} \mathrm{CDCl}_{3}\right): \delta=7.69$ (d, J = 4.2 Hz, 1H, 23-H), $7.51-7.46(\mathrm{~m}$, 2H, 2-H, 6-H), $7.44-7.38$ (m, 2H, 3-H, 5-H), 7.28 (d, J = 7.2 Hz, 1H, 24-H), 6.67 (d, J = 4.2 Hz, 1H, 4-H), 4.86 (s, 1H, 15-H), 2.53 (s, 3H, 10-H), 2.23 (s, 3H, 19-H), 2.03 (s, 3H, 17-H) ppm; ${ }^{13} \mathrm{C}$ NMR (126 MHz, $\left.\mathrm{CDCl}_{3}\right): \delta=198.0$ (C-18), 157.6 (C-12), 157.5 (C-11), 153.2 (C-7), 149.3 (C-21), 142.5 (C-13), 138.0 (C-9), 136.3 (C-1), 131.0 (C-2, C-6), 130.6 (C-3, C-5), 129.5 (C-23), 124.8 (C-24), 123.7 (C-4), 118.9 (C-22), 115.9 (C-14), 95.3 (C-8), 65.1 (16), 36.5 (15), 30.3 (19), 17.7 (17), 13.8 (10) ppm; MS (ESI, MeOH): m/z 507 (100\%, [M+Na]+); analysis calcd for $\mathrm{C}_{24} \mathrm{H}_{19} \mathrm{~N}_{7} \mathrm{O}_{3} \mathrm{~S}$ (485.52): C 59.37, $\mathrm{H} 3.94, \mathrm{~N} 20.19$, S 6.60; found: C 59.17, H 4.18, N 20.02, S 6.43 .

\subsection{8-Acetyl-4-amino-3,9-dimethyl-7-(2-naphthyl)-1-phenyl-1,7-dihydropyrazolo[4,3-e] pyrido[1,2-a]pyrimidine-6-carbonitrile (7k)}

Yield: 65\%; m.p. $270{ }^{\circ} \mathrm{C}$; $\mathrm{RF}_{\mathrm{F}}=0.49\left(\mathrm{SiO}_{2}, \mathrm{CHCl}_{3} / \mathrm{MeOH}, 95: 5\right)$; UV-Vis $\left(\mathrm{CHCl}_{3}\right): \lambda_{\max }$ $(\log \varepsilon)=270 \mathrm{~nm}(4.37) ;$ IR (ATR): $v=3468 \mathrm{w}, 2181 \mathrm{~m}, 1676 \mathrm{~m}, 1654 \mathrm{~m}, 1611 \mathrm{~m}, 1543 \mathrm{~s}, 1479 \mathrm{~m}$, $1357 \mathrm{~m}, 1244 \mathrm{~m}, 1222 \mathrm{w}, 951 \mathrm{w}, 879 \mathrm{w}, 762 \mathrm{~m}, 754 \mathrm{~m}, 695 \mathrm{~m}, 621 \mathrm{w}, 515 \mathrm{~m}, 479 \mathrm{~m} \mathrm{~cm}^{-1}$; ${ }^{1} \mathrm{H}$ NMR $\left(500 \mathrm{MHz}_{\mathrm{CDCl}}\right): \delta=7.89-7.80(\mathrm{~m}, 3 \mathrm{H}, 23-\mathrm{H}, 25-\mathrm{H}, 28-\mathrm{H}), 7.69(\mathrm{t}, \mathrm{J}=1.5 \mathrm{~Hz}, 1 \mathrm{H}, 30-\mathrm{H})$, $7.51-7.41(\mathrm{~m}, 3 \mathrm{H}, 22-\mathrm{H}, 26-\mathrm{H}, 27-\mathrm{H}), 7.22(\mathrm{tt}, \mathrm{J}=7.3,1.0 \mathrm{~Hz}, 2 \mathrm{H}, 2-\mathrm{H}, 6-\mathrm{H}), 7.04$ (t, J = 8.1 $\mathrm{Hz}, 2 \mathrm{H}, 3-\mathrm{H}, 5-\mathrm{H}), 6.60(\mathrm{~d}, \mathrm{~J}=7.5 \mathrm{~Hz}, 1 \mathrm{H}, 4-\mathrm{H}), 5.23-5.06$ (m, 1H, 15-H), 2.60 (s, 3H, 10-H), 2.45 (s, 3H, 19-H), 1.69 (s, 3H, 17-H) ppm; ${ }^{13} \mathrm{C} \mathrm{NMR} \mathrm{(126} \mathrm{MHz,} \mathrm{CDCl3):} \delta=198.1$ (C-18), 155.7 (C-12), 155.2 (C-11), 145.6 (C-7), 143.7 (C-13), 141.3 (C-9), 139.0 (C-21), 137.8 (C-1), 133.3 (C-29), 132.8 (C-24), 129.7 (C-3, C-5), 128.6 (C-2, C-6), 128.6 (C-23), 128.0 (C-25), 127.8 (C-28), 126.7 (C-26), 126.3 (C-27), 125.3 (C-22), 125.1 (C-20), 124.8 (C-30), 122.6 (C-4), 122.4 (C-14), 99.9 (C-8), 71.5 (C-16), 40.7 (C-15), 30.6 (C-19), 19.4 (C-17), 13.8 (C-10) ppm; MS (ESI, MeOH): m/z $485\left(100 \%,[\mathrm{M}+\mathrm{H}]^{+}\right), 606\left(24 \%,[\mathrm{M}+\mathrm{Na}]^{+}\right)$; analysis calcd for $\mathrm{C}_{30} \mathrm{H}_{24} \mathrm{~N}_{6} \mathrm{O}$ (484.55): C 74.36, H 4.99, N 17.34; found: C 74.19, H 5.18, N 17.08.

\subsection{8-Acetyl-4-amino-3,9-dimethyl-1-phenyl-7-pyridin-3-yl-1,7-dihydropyrazolo[4,3-e] pyrido[1,2-a]pyrimidine-6-carbonitrile (7l)}

Yield: 68\%; m.p. $306{ }^{\circ} \mathrm{C} ; \mathrm{R}_{\mathrm{F}}=0.44\left(\mathrm{SiO}_{2}, \mathrm{CHCl}_{3} / \mathrm{MeOH}, 95: 5\right) ; \mathrm{UV}-\mathrm{Vis}\left(\mathrm{CHCl}_{3}\right)$ : $\lambda \max (\log \varepsilon)=269 \mathrm{~nm}(4.34) ; \mathrm{IR}(\mathrm{ATR}): v=3398 \mathrm{w}, 2193 \mathrm{~m}, 1651 \mathrm{~m}, 1621 \mathrm{~s}, 1570 \mathrm{~m}, 1537 \mathrm{~s}$, $1474 \mathrm{~m}, 1325 \mathrm{~m}, 1232 \mathrm{~m}, 1174 \mathrm{~m}, 1025 \mathrm{~m}, 957 \mathrm{w}, 877 \mathrm{w}, 759 \mathrm{~m}, 716 \mathrm{~m}, 689 \mathrm{~m}, 623 \mathrm{~m}, 572 \mathrm{~m}, 511 \mathrm{~m}$ $\mathrm{cm}^{-1} ;{ }^{1} \mathrm{H}$ NMR $\left(500 \mathrm{MHz} \mathrm{CDCl}_{3}\right): \delta=8.58(\mathrm{~d}, \mathrm{~J}=4.0 \mathrm{~Hz}, 1 \mathrm{H}, 23-\mathrm{H}), 8.52(\mathrm{~d}, \mathrm{~J}=2.4 \mathrm{~Hz}, 1 \mathrm{H}$, 22-H), 7.79 (d, J = 7.9 Hz, 1H, 25-H), $7.42-7.27$ (m, 5H, 2-H, 3-H, 5-H, 6-H, 24-H), 6.65 (d, J $=7.4 \mathrm{~Hz}, 1 \mathrm{H}, 4-\mathrm{H}), 5.08(\mathrm{~s}, 1 \mathrm{H}, 15-\mathrm{H}), 2.58(\mathrm{~s}, 3 \mathrm{H}, 10-\mathrm{H}), 2.37(\mathrm{~s}, 3 \mathrm{H}, 19-\mathrm{H}), 1.70(\mathrm{~s}, 3 \mathrm{H}$, 17-H) ppm; ${ }^{13} \mathrm{C}$ NMR (126 MHz, CDCl $): \delta=196.8$ (C-18), 156.3 (C-12), 155.1 (C-11), 147.2 (C-23), 147.1 (C-22), 145.3 (C-7), 144.3 (C-13), 140.9 (C-9), 137.5 (C-1), 135.8 (C-25), 129.7 (C-3, C-5), 128.7 (C-2, C-6), 124.2 (C-20), 123.7 (C-21), 122.4 (C-4), 121.8 (C-14), 100.0 (C-8), 69.8 (C-16), 38.1 (C-15), 30.7 (C-19), 19.1 (C-17), 13.5 (C-10) ppm; MS (ESI, MeOH): m/z $436\left(100 \%,[\mathrm{M}+\mathrm{H}]^{+}\right)$; analysis calcd for $\mathrm{C}_{25} \mathrm{H}_{21} \mathrm{~N} 7 \mathrm{O}$ (435.48): C 68.95, H 4.86, N 22.51; found: C 68.80, H 4.97, N 22.31. 


\section{Conclusions}

In summary, a new class of pyrazolo[4,3-e]pyrido[1,2-a]pyrimidine derivatives was designed, synthesized, characterized and evaluated for their cytotoxic activity towards five human cancer cell lines A375, HT-29, MCF-7, A2780, FaDu, as well as non-malignant NIH 3T3 and HEK293. Compound 7e displayed a noteworthy cytotoxic effect towards all cancer cell lines. A SAR study demonstrated that fused heterocycles pyrazole, pyridine and pyrimidine and group linked to the aryl moiety E in para position especially the presence of a bromine substituent seem to play a crucial role in the cytotoxic activities. Besides, the molecular docking indicate that this class of heterocyclic molecules exhibits important binding energy and interaction with interesting residues of anticancer target such as, DHFR, VEGFR2, HER-2/neu, hCA-IX, CDK6 and LOX.

Supplementary Materials: The following are available online at www.mdpi.com/xxx/s1, details of the SRB assay, and depicted NMR $\left({ }^{1} \mathrm{H},{ }^{13} \mathrm{C}\right)$ and IR spectra of the compounds 3, 5 and $7 \mathrm{a}-7 \mathbf{l}$.

Author Contributions: H.B.J. and R.C. brought the idea, managed the research, and prepared the manuscript; M.H. and A. R. prepared compounds for screening, M.H., A.H.H. and A.R. draft preparation, S.H. and N.H. conducted biological experiments and characterization. All authors have read and agreed to the published version of the manuscript.

Funding: We acknowledge the financial support within the funding program Open Access Publishing by the German Research Foundation (DFG).The authors also express thanks to the Ministry of Higher Education and Scientific Research of Tunisia for financial support (LR11ES39).

Institutional Review Board Statement: Not applicable.

Informed Consent Statement: Not applicable.

Acknowledgments: We like to thank D. Ströhl and his team for the NMR spectra and T. Schmidt for numerous MS spectra; IR, UV/vis spectra and elemental analyses were measured by M. Schneider; the cell lines were kindly provided by Th. Müller (Dep. of Haematology/Oncology, Martin-Luther University Halle-Wittenberg). We are also grateful to Researchers Supporting Project number (RSP-2021/17) at King Saud University, Riyadh, Saudi Arabia.

Conflicts of Interest: The authors declare no conflict of interest. 


\section{References}

1. Torre, L. A.; Bray, F.; Siegel, R. L.; Ferlay, J.; Lortet-Tieulent, J.; Jemal, A., Global Cancer Statistics, 2012. CA-Cancer J Clin 2015, $65,(2), 87-108$.

2. Isakoff, S. J., Triple-Negative Breast Cancer Role of Specific Chemotherapy Agents. Cancer J 2010, 16, (1), 53-61.

3. Nossier, E. S.; Fahmy, H. H.; Khalifa, N. M.; El-Eraky, W. I.; Baset, M. A., Design and Synthesis of Novel Pyrazole-Substituted Different Nitrogenous Heterocyclic Ring Systems as Potential Anti-Inflammatory Agents. Molecules 2017, $22,(4), 512-528$.

4. Chekir, S.; Debbabi, M.; Regazzetti, A.; Dargere, D.; Laprevote, O.; Ben Jannet, H.; Gharbi, R., Design, synthesis and biological evaluation of novel 1,2,3-triazole linked coumarinopyrazole conjugates as potent anticholinesterase, anti-5-lipoxygenase, anti-tyrosinase and anti-cancer agents. Bioorg Chem 2018, 80, 189-194.

5. El-Naggar, M.; Hassan, A. S.; Awad, H. M.; Mady, M. F., Design, Synthesis and Antitumor Evaluation of Novel Pyrazolopyrimidines and Pyrazoloquinazolines. Molecules 2018, 23, (6), 189-194.

6. Somakala, K.; Tariq, S.; Amir, M., Synthesis, evaluation and docking of novel pyrazolo pyrimidines as potent p38 alpha MAP kinase inhibitors with improved anti-inflammatory, ulcerogenic and TNF-alpha inhibitory properties. Bioorg Chem 2019, 87, 550-559.

7. Rahmouni, A.; Souiei, S.; Belkacem, M. A.; Romdhane, A.; Bouajila, J.; Ben Jannet, H., Synthesis and biological evaluation of novel pyrazolopyrimidines derivatives as anticancer and anti-5-lipoxygenase agents. Bioorg Chem 2016, 66, $160-168$.

8. Rahmouni, A.; Romdhane, A.; Ben Said, A.; Majouli, K.; Ben Jannet, H., Synthesis of new pyrazole and antibacterial pyrazolopyrimidine derivatives. Turk J Chem 2014, 38, (2), 210-221.

9. De Vita, D.; Pandolfi, F.; Cirilli, R.; Scipione, L.; Di Santo, R.; Friggeri, L.; Mori, M.; Fiorucci, D.; Maccari, G.; Christopher, R. S. A.; Zamperini, C.; Pau, V.; De Logu, A.; Tortorella, S.; Botta, M., Discovery of in vitro antitubercular agents through in silico ligand-based approaches. Eur J Med Chem 2016, 121, 169-180.

10. Al-Aldiwish, W. M.; Shtewi, F. A.; Ashrif, M. M.; Ibrahim, D. M., Synthesis, biolovical activity and cytotoxicity of new fused pyrazolo[1,5-a]pyrimidine from 5-aminopyrazole incoroporated with p-chloroaniline. American J. Heterocycl. Chem. 2017, 3 , 86-94.

11. Alharthy, R. D., Design and Synthesis of Novel Pyrazolo[3,4-d]Pyrimidines: In Vitro Cytotoxic Evaluation and Free Radical Scavenging Activity Studies. Pharmaceutical Chemistry Journal 2020, 54, (3), 273-278.

12. Fouda, A. M.; Abbas, H. A. S.; Ahmed, E. H.; Shati, A. A.; Alfaifi, M. Y.; Elbehairi, S. E. I., Synthesis, In Vitro Antimicrobial and Cytotoxic Activities of Some New Pyrazolo[1,5-a]pyrimidine Derivatives. Molecules 2019, 24, (6), 1080.

13. Husseiny, E. M., Synthesis, cytotoxicity of some pyranzoles and pyrazolo[1,5-a]pyrimidines bearing benzothiazole moiety amd investigation of their mechanism of action. Bioorg. Chem. 2020, 102, 104053.

14. Zhang, H. J.; Wang, S. B.; Wen, X.; Li, J. Z.; Quan, Z. S., 5Y Design, synthesis, and evaluation of the anticonvulsant and antidepressant activities of pyrido[2,3-d]pyrimidine derivatives. Med Chem Res 2016, 25, (7), 1287-1298.

15. Abdelaziz, O. A.; El Husseiny, W. M.; Selim, K. B.; Eisa, H. M., Dihydrofolate reductase inhibition effect of 5-substituted pyrido[2,3-d] pyrimidines: Synthesis, antitumor activity and molecular modeling study. Bioorg Chem 2019, 90, 103076.

16. Ibrahim, D. A.; Ismail, N. S. M., Design, synthesis and biological study of novel pyrido[2,3-d]pyrimidine as anti-proliferative CDK2 inhibitors. Eur J Med Chem 2011, 46, (12), 5825-5832.

17. Hanafy, F. I., Synthesis and antifungal activity of some new pyrido[2,3-d]pyrimidines. 2011 2011, $2,(1), 5$.

18. Gfesser, G. A.; Bayburt, E. K.; Cowart, M.; DiDomenico, S.; Gomtsyan, A.; Lee, C. H.; Stewart, A. O.; Jarvis, M. F.; Kowaluk, E. A.; Bhagwat, S. S., Synthesis and structure-activity relationships of 5-heteroatom-substituted pyridopyrimidines as adenosine kinase inhibitors. Eur J Med Chem 2003, 38, (3), 245-252.

19. Moreno, E.; Plano, D.; Lamberto, I.; Font, M.; Encio, I.; Palop, J. A.; Sanmartin, C., Sulfur and selenium derivatives of quinazoline and pyrido[2,3-d]pyrimidine: Synthesis and study of their potential cytotoxic activity in vitro. Eur J Med Chem 2012, 47, 283-298.

20. Sanmartin, C.; Echeverria, M.; Mendivil, B.; Cordeu, L.; Cubedo, E.; Garcia-Foncillas, J.; Font, M.; Palop, J. A., Synthesis and biological evaluation of new symmetrical derivatives as cytotoxic agents and apoptosis inducers. Bioorgan Med Chem 2005, 13, (6), 2031-2044.

21. Alam, R.; Alam, A.; Amulya, K. P.; Rahisuddin, Design, synthesis and cytotoxicity evaluation of pyrazolyl pyrazoline and pyrazolyl aminopyrimidine derivatives as potential anticancer agents. Med Chem Res 2018, 27, 560-570.

22. Lee, J.; Kim, K. H.; Jeong, S.; Discovery of a novel class of 2-aminopyrimidines as CDK1 and CDK2 inhibitors, Bioorg. Med. Chem. Lett 2011, 21, 4203- 4205.

23. Sabour, R.; Harras, M. F.; Mehany, A. B. M., Design, Synthesis, Cytotoxicity Screening and Molecular Docking of New 3Cyanopyridines as Survivin inhibitors and Apoptosis Inducers. Bioorg Chem 2019, doi: https://doi.org/10.1016/j.bioorg.2019.103358

24. Al-Refai, M.; Ibrahim, M.M.; Nurul Azmi, M.; Osman, H.; Abu Bakar, M.H.; Geyer, A., The Synthesis, Characterization, Cytotoxic Activity Assessment and Structure-Activity Relationship of 4-Aryl-6-(2,5-dichlorothiophen-3-yl)-2-methoxypyridine-3-carbonitriles. Molecules 2019, $24,4072$.

25. Ragab, F. A.; Nissan, Y. M.; Seif, E. M.; Maher, A.; Arafa, R. K., Synthesis and in vitro investigation of novel cytotoxic pyrimidine and pyrazolopyrimidne derivatives showing apoptotic effect. Bioorg Chem 2020, 96, 103621.

26. Haiba, M. E.; Al-Abdullah, E. S.; Ahmed, N. S.; Ghabbour, H. A.; Awad, H. M., Efficient and easy synthesis of new Benzo[h]chromene and Benzo[h] quinoline derivatives as a new class of cytotoxic agents. J Mol Struct 2019, 1195, 702-711. 
27. Debbabi, M.; Nimbarte, V. D.; Chekir, S.; Chortani, S.; Romdhane, A.; Ben Jannet, H., Design and synthesis of novel potent anticoagulant and anti-tyrosinase pyranopyrimidines and pyranotriazolopyrimidines: Insights from molecular docking and SAR analysis. Bioorg Chem 2019, 82, 129-138.

28. Horchani, M.; Della Sala, G.; Caso, A.; D'Aria, F.; Esposito, G.; Laurenzana, I.; Giancola, C.; Costantino, V.; Ben Jannet, H.; Romdhane, A., Molecular Docking and Biophysical Studies for Antiproliferative Assessment of Synthetic Pyrazolo-Pyrimidinones Tethered with Hydrazide-Hydrazones. Int J Mol Sci 2021, 22, (5), 2742.

29. Romdhane, A.; Martin, M. T.; Ben Said, A.; Jabrane, A.; Ben Jannet, H., Synthesis of new naphto[2,1-b]pyrano[3,2-e][1,2,4]triazolo[1,5-c]pyrimidine derivatives and their evaluation as acetylcholinesterase inhibitors. J. Soc. Chim. Tun. 2012, 14, 127-131.

30. Horchani, M.; Hajlaoui, A.; Harrath, A. H.; Mansour, L.; Ben Jannet, H.; Romdhane, A., New pyrazolo-triazolo-pyrimidine derivatives as antibacterial agents: Design and synthesis, molecular docking and DFT studies. J Mol Struct 2020, 1199.

31. Aliwaini, S.; Abu Thaher, B.; Al-Masri, I.; Shurrab, N.; El-Kurdi, S.; Schollmeyer, D.; Qeshta, B.; Ghunaim, M.; Csuk, R.; Laufer, S.; Kaiser, L.; Deigner, H. P., Design, Synthesis and Biological Evaluation of Novel Pyrazolo[1,2,4]triazolopyrimidine Derivatives as Potential Anticancer Agents. Molecules 2021, 26, (13), 26134065.

32. Saeed, A.; Hussain, H.; Shamraiz, U.; Rehman, N. U.; Khan, H. Y.; Badshah, A.; Heller, L.; Csuk, R.; Ali, M.; Khan, A.; Al-Harrasi, A., Synthesis of new triterpenic monomers and dimers as potential antiproliferative agents and their molecular docking studies. Eur J Med Chem 2018, 143, 948-957.

33. Ruddarraju, R. R.; Murugulla, A. C.; Kotla, R.; Tirumalasetty, M. C. B.; Wudayagiri, R.; Donthabakthuni, S.; Maroju, R.; Baburao, K.; Parasa, L. S., Design, synthesis, anticancer, antimicrobial activities and molecular docking studies of theophylline containing acetylenes and theophylline containing 1,2,3-triazoles with variant nucleoside derivatives. Eur J Med Chem 2016, 123, 379-396.

34. Berman, H. M.; Westbrook, J.; Feng, Z.; Gilliland, G.; Bhat, T. N.; Weissig, H.; Shindyalov, I. N.; Bourne, P. E., The Protein Data Bank. Nucleic Acids Res 2000, 28, (1), 235-242.

35. Cody, V.; Gangjee, A., Human dihydrofolate reductase ternary complex with a series of fluorine substituted 5-methyl-6-(phenylthio)thieno[2,3-d]pyrimidine-2,4-diamines. DOI:102210/pdb5HQY/pdb.

36. Bold, G.; Schnell, C.; Furet, P.; McSheehy, P.; Bruggen, J.; Mestan, J.; Manley, P. W.; Druckes, P.; Burglin, M.; Durler, U.; Loretan, J.; Reuter, R.; Wartmann, M.; Theuer, A.; Bauer-Probst, B.; Martiny-Baron, G.; Allegrini, P.; Goepfert, A.; Wood, J.; Littlewood-Evans, A., A Novel Potent Oral Series of VEGFR2 Inhibitors Abrogate Tumor Growth by Inhibiting Angiogenesis. J Med Chem 2016, 59, (1), 132-146.

37. Ishikawa, T.; Seto, M.; Banno, H.; Kawakita, Y.; Oorui, M.; Taniguchi, T.; Ohta, Y.; Tamura, T.; Nakayama, A.; Miki, H.; Kamiguchi, H.; Tanaka, T.; Habuka, N.; Sogabe, S.; Yano, J.; Aertgeerts, K.; Kamiyama, K., Design and Synthesis of Novel Human Epidermal Growth Factor Receptor 2 (HER2)/Epidermal Growth Factor Receptor (EGFR) Dual Inhibitors Bearing a Pyrrolo[3,2-d]pyrimidine Scaffold. J Med Chem 2011, 54, (23), 8030-8050.

38. Leitans, J.; Kazaks, A.; Balode, A.; Ivanova, J.; Zalubovskis, R.; Supuran, C. T.; Tars, K., Efficient Expression and Crystallization System of Cancer-Associated Carbonic Anhydrase Isoform IX. J Med Chem 2015, 58, (22), 9004-9009.

39. Cho, Y. S.; Borland, M.; Brain, C.; Chen, C. H. T.; Cheng, H.; Chopra, R.; Chung, K.; Groarke, J.; He, G.; Hou, Y.; Kim, S.; Kovats, S.; Lu, Y. P.; O'Reilly, M.; Shen, J. Q.; Smith, T.; Trakshel, G.; Vogtle, M.; Xu, M.; Xu, M.; Sung, M. J., 4-(Pyrazol-4-yl)-pyrimidines as Selective Inhibitors of Cyclin-Dependent Kinase 4/6. J Med Chem 2010, 53, (22), 7938-7957.

40. Gilbert, N. C.; Rui, Z.; Neau, D. B.; Waight, M. T.; Bartlett, S. G.; Boeglin, W. E.; Brash, A. R.; Newcomer, M. E., Conversion of human 5-lipoxygenase to a 15-lipoxygenase by a point mutation to mimic phosphorylation at Serine-663. FASEB J 2012, 26, (8), 3222-3229. 